\title{
ANTICORPOS FIXADORES DE COMPLEMENTO PARA O VIRUS RESPIRATÓRIO SINCICIAL E ADENOVIRUS E INIBIDORES DA HEMAGLUTINAÇĀO PARA OS VIRUS PARAINFLUENZA 1, 2 E 3 NUMA POPULAÇÃO INFANTIL BRASILEIRA (1)
}

\begin{abstract}
Apresentaram-se os resultados obtidos na pesquisa de anticorpos fixadores de complemento para o virus respiratório sincicial e adenovírus, assim como de anticorpos inibidores da hemaglutinacão para os vírus parainfluenza dos tipos 1, 2 e 3, num grupo de 972 criangas de idade compreendida entre 3 meses $\theta$ 14 anos. A técnica de colheita de sangue foi a de embebição em papel de filtro. Do total de erianças examinadas, considerando o conjunto de tôdas as idades, 34,6\% apresentavam anticorpos para o virus respiratório sincicial; as porcentagens com anticorpos para adenovirus, parainfluenza 1 , parainfluenza 2 e parainfluenza 3, foram respectivamente $47,7 \%, 46,8 \%, 54,1 \%$ e $66,6 \%$. Foram estudadas as distribuições dos anticorpos em função da idade, do sexo $\Theta$ da localizacão do domicílio. Em relacão aos dois últimos atributos obtiveram-se os seguintes resultados: dos individuos do sexo masculino, 32,3\% apresentavam anticorpos contra o virus respiratorio sincicial, $49,2 \%$ contra adenovírus, $60,1 \%$, $65,1 \%$ - 78,3\%, respectivamente, contra os vírus parainfluenza 1,2 e 3 ; nas criancas do sexo feminino as porcentagens de positividade encontradas foram, respectivamente, $37,4 \%, 45,9 \%, 31,1 \%, 41,2 \%$ e $52,9 \%$; em relacão à localizacão do domicilio, $44,8 \%$ do total de criancas da zona rural mostraram possuir anticorpos contra o virus respiratório sincicial, $70,1 \%$ contra adenovírus, 43,8\% contra virus parainfluenza 1 e $46,8 \%$ e $65,4 \%$ contra os virus parainfluenza dos tipos 2 e 3; as porcentagens de positividade na zona urbana foram, respectiva-. mente, $30,5 \%, 38,7 \%, 47,9 \%, 57,1 \%$ e $67,1 \%$.
\end{abstract}

\section{N T R O D U CAO}

A Saúde Pública confronta-se com uma escala de problemas, cuja prioridade, no que diz respeito a uma possível solução, vai corresponder, sistemàticamente, às condiçōes sócio-econômicas locais. É esta a razão pela qual os problemas focalizados nos países desenvolvidos não são os mesmos dạs estruturas menos avançadas onde, de um modo geral, as doenças infecciosas constiuem o centro da atenção dos especialistas. As doenças respirató- rias agudas, entretanto, quer se apresentem sob a forma de casos esporádicos, epidemias localizadas ou pandemias, formam um denominador comum a ambas as estruturas.

Estão incluídas na designação de doenças respiratórias agudas a vírus, a influenza e todo um conjunto de outras infecções que ocasionam condições clínicas complexas e nas quais parecem ser particularmente importantes os seguintes

(1) Da Cadeira de Microbiologia Aplicada da Faculdade de Higlene e Saúde Públlca da USP. - Resumo da Tese de Doutoramento, apresentada à Faculdade de Higiene e Saúde Pública da USP, em 1968. 
CANDEIAS, J. A. N. - Anticorpos fixadores de complemento para o virus respiratório sincicial e adenovírus. Rev. Saúde públ., S. Paulo, 2(1):44-67, jun. 1968.

vírus: vírus parainfluenza 1-4, (KUROYA et alii ${ }^{54}$; Chanock ${ }^{17}$, 1956; Chanock et alii ${ }^{18}, 1958$ e Johnson et alii ${ }^{48}$, 1960), vírus respiratório sincicial (MorRIS, Blount \& Savage ${ }^{60}$, 1956; ChaNOCK, RoIzMan \& MYers $\left.{ }^{16}, 1957\right)$, adenovírus (Rowe et alii ${ }^{71}, 1953$ ), mais freqüentemente dos tipos $1,2,3,4,5$, 7, 14 e 21, vírus Coxsackie (DaLldorF \& Sickles ${ }^{25}, 1948$ ) dos tipos A2-7, A9, A21, B1-5, vírus ECHO (COMMITTEE oN Echo VIRUSEs ${ }^{123}, 1956$ ) dos tipos 6, 11 e 20, rinovírus (ANDREWEs et alii ${ }^{12}, 1953$ ) e vírus REO (Stanley, Dorman \& PONSFORd ${ }^{79}, 1954$ ).

Apesar de extenso, parece ser ainda insuficiente o número de pesquisas feitas no sentido de elucidar a participação de todos os vírus referidos naquela multiplicidade de condições clínicas, muito embora se suspeite que, de um modo geral, os rinovírus parecem ser importantes no resfriado comum, os vírus parainfluenza na laringotraqueobronquite aguda, o vírus respiratório sincicial na bronquiolite aguda e os adenovírus na pneumonite viral.

E nosso objetivo conhecer a distribuição, segundo determinados atributos, dos anticorpos fixadores de complemento para o vírus respiratório sincicial e para adenovírus e dos anticorpos inibidores da hemaglutinação para os vírus parainfluenza 1,2 e 3 , num grupo de crianças de 0 a 14, anos. De posse desta informação, poderemos ter uma idéia da freqüência e distribuição das infecções respiratórias ocasionadas por êstes vírus como ponto de partida para uma pesquisa ulterior, mais ampla, que visa conhecer seu comportamento e sua importância, em ambiente familiar, não só através de estudos sorológicos, mas também de isolamento dos agentes etiológicos referidos.

\section{MATERIAL E METODOS}

Amostragem - Foram colhidos 972 espécimens de sangue de crianças, sem qualquer quadro clínico respiratório ou entérico, inscritas no Serviço Especial de Saúde de Araraquara (SESA) e que recorreram a seus serviços médico-assistenciais entre 7 de dezembro de 1966 e 18 de abril de 1967. Dêste total, 526 espécimens provinham de crianças do sexo masculino e 446, do sexo feminino. No que respeita à localização do domicílio, 694 espécimens correspondiam a crianças da zona urbana e 278 a crianças da zona rural, dentro do critério de classificação em zona urbana e rural adotado pelo SESA. Estabelece êste ser necessário que existam serviços públicos municipais para que determinada comunidade seja considerada como pertencendo à zona urbana. $\mathrm{O}$ critério adotado não considera a existência de zona suburbana.

Foi feita uma só colheita de sangue das crianças atendidas, com idade compreendida entre 0 a 14 anos, de tal modo que, em cada mês, houvesse uma distribuição etária sensìvelmente semelhante e, ao mesmo tempo, um número, aproximadamente, igual de indivíduos em cada grupo.

O método de amostragem circunstancial utilizado não é o mais satisfatório, mas achamos que o material obtido se presta à pesquisa a que nos propusemos, tendo em vista que não pretendemos tirar, dos resultados obtidos, conclusōes aplicáveis à população infantil do município de Araraquara, mas, tão sòmente, analisá-los em relação ao total de crianças inscritas no SESA.

Apesar de nos empenharmos em estabelecer a presença de circunstâncias anormais que pudessem determinar grandes diferenças de probabilidade, de uma criança para outra, de pertencer à amostra estudada, aquelas não pareceram ter estado presentes entre 7 de dezembro de 1966 a 18 de abril de 1967. Acreditamos que as crianças que fazem parte do grupo estudado tiveram, aproximadamente, a mesma probabilidade de pertencer à amostra, do que crianças não incluídas naquele grupo. 
CANDEIAS, J. A. N. - Anticorpos fixadores de complemento para o virus respiratório sincicial e adenovirus. Rev. Saúde públ., S. Paulo, 2(1):44-67, Jun. 1968.

Tivemos, assim, a oportunidade de determinar o tamanho da amostra a estudar, em cada grupo etário, seguindo as mesmas regras aplicadas à amostragem equi-probabilística. Desconhecendo nós qual a proporção de distribuição dos títulos de anticorpos para os vírus estudados, para cada domínio, consideramos que a mesma deveria obedecer à pior das distribuições, isto é, àquela que admite $50 \%$ de positivos $(\mathrm{P}=0,5)$ e $50 \%$ de negativos $(Q=0,5)$.

Estabelecendo ainda que admitiríamos um êrro de amostragem de, no máximo, $5 \%(\mathrm{~d}=0,05)$ e que aceitaríamos uma probabilidade de $5 \%$ de selecionarmos uma amostra cujo êrro de amostragem ultrapasse " $d$ " em valor absoluto, criamos limitaçóes que levaram ao cálculo dos valores que deveriam ter os tama. nhos das amostras, a fim de alcançarmos a precisão desejada. São êstes: 317 para a classe de crianças de idade inferior a 1 ano, 341 para a classe de crianças de idade compreendida entre 1 e 6 anos e de 330 para a classe de crianças de idade compreendida entre 7 e 14 anos. Realmente, o tamanho das amostras estudadas é o que figura na Tabela 1 , onde também pode ver-se o número de crianças inscritas no SESA, no período durante o qual foi feita a colheita de sangue.
O tamanho das amostras para as classes de 1 a 6 anos e 7 a 14 anos ultrapassa o requerido. Com relação à clas. se de idade inferior a 1 ano, embora $o$ tamanho calculado tivesse sido de 317 crianças, não houve possibilidade de obter uma amostra com tal grandeza, de forma que teremos de aceitar uma margem de êrro de $9 \%$, em substituição àquela de 5\%. Devemos ainda chamar a atenção para o fato de, nesta classe, não se encontrar nenhuma criança de 1 e 2 meses de idade, o que ocorreu pela circunstância de, durante o período de colheita, não terem aparecido na consulta médica crianças com aquela idade. Assim sendo, quando nos referimos à classe de crianças de idade inferior a 1 ano, sig. nificamos o conjunto de crianças com idade compreendida entre 3 meses e 11 meses.

Nas Tabelas 2, 3 e 4 apresentamos as distribuições mensais das crianças de 1 a 14 anos examinadas, segundo a idade, sexo e localização do domicílio.

A fim de verificarmos se a estrutura mensal, em têrmos de idade, sexo e localização do domicílio, era semelhante, durante o período da colheita, foi feito para cada tabela, um teste de significância de diferenças de proporção (GoLD ${ }^{37}, 1962$ ) ao nível de $5 \%$. Os resultados obtidos revelam que as diferenças observadas não são estatìsticamente significativas.

TABELA 1

Dístribuição das crianças estudadas e das crianças inscritas no SESA, no periodo 7 de dezembro de 1966 - 18 de abril de 1967, segundo a idade

\begin{tabular}{c|c|c|c|c}
\hline \multirow{2}{*}{ Idade em anos } & \multicolumn{2}{c|}{ Crianças inscritas } & \multicolumn{2}{c}{ Crianças estudadas } \\
\cline { 2 - 5 } & N.0 & $\%$ & N.0 & $\%$ \\
\hline$<1$ & 1.814 & 23,9 & 126 & 12,9 \\
1 |- 6 & 3.404 & 44,9 & 461 & 47,4 \\
7 |- 14 & 2.347 & 31,2 & 385 & 39,7 \\
Total & 7.565 & 100,0 & 972 & 100,0 \\
\hline
\end{tabular}


CANDEIAS, J. A. N. - Anticorpos fixadores de complemento para o vírus resplratório sincicial e adenovirus. Rev. Saude públ., S. Paulo, 2(1):44-67, jun. 1968.

TABELA 2

Distribulção mensal das crianças de 1 a 14 anos, inscritas no SESA e examinadas no periodo 7 de dezembro de 1966 - 18 de abril de 1967, segundo a idade

\begin{tabular}{|c|c|c|c|c|c|c|c|c|c|}
\hline \multirow{3}{*}{$\begin{array}{c}\text { Idade } \\
\text { (em anos) }\end{array}$} & \multirow{3}{*}{$\begin{array}{l}\text { Número de } \\
\text { criancas } \\
\text { examinadas }\end{array}$} & \multicolumn{8}{|c|}{$\mathbf{M}$ ê $\mathbf{s}$} \\
\hline & & \multicolumn{2}{|c|}{ Dezembro } & \multicolumn{2}{|c|}{ Jan./Fev. } & \multicolumn{2}{|c|}{ Marco } & \multicolumn{2}{|c|}{ Abril } \\
\hline & & N.o & $\%$ & N.o & $\%$ & N. ${ }^{\circ}$ & $\%$ & N.o & $\%$ \\
\hline $1-16$ & 461 & 146 & 56,2 & 139 & 55,6 & 73 & 54,9 & 103 & 50,7 \\
\hline $7|-| 14$ & 385 & 114 & 43,8 & 111 & 44,4 & 60 & 45,1 & 100 & 49,3 \\
\hline Total & 846 & 260 & 100,0 & 250 & 100,0 & 133 & 100,0 & 203 & 100,0 \\
\hline
\end{tabular}

T A B ELA 3

Distribuição mensal das crianças de 1 a 14 anos, inscritos no SESA e examinadas no perfodo 7 de dezembro de $1966-18$ de abril de 1967, segundo o sexo

\begin{tabular}{|c|c|c|c|c|c|c|c|c|c|}
\hline \multirow{3}{*}{ Sexo } & \multirow{3}{*}{$\begin{array}{l}\text { Número de } \\
\text { crianças } \\
\text { examinadas }\end{array}$} & \multicolumn{8}{|c|}{$M$ ê $\mathrm{s}$} \\
\hline & & \multicolumn{2}{|c|}{ Dezembro } & \multicolumn{2}{|c|}{ Jan./Fev. } & \multicolumn{2}{|c|}{ Marco } & \multicolumn{2}{|c|}{ Abril } \\
\hline & & N.o & $\%$ & N.o & $\%$ & N.o & $\%$ & N. ${ }^{\circ}$ & $\%$ \\
\hline Masculino & 458 & 134 & 51,6 & 142 & 56,8 & 69 & 51,8 & 113 & 55,6 \\
\hline Feminino & 388 & 126 & 48,4 & 108 & 43,2 & 64 & 48,2 & 90 & 44,4 \\
\hline Total & 846 & 260 & 100,0 & 250 & 100,0 & 133 & 100,0 & 203 & 100,0 \\
\hline
\end{tabular}

T A B EL A 4

Distribuição mensal das crianças de 1 a 14 anos, inscritas no SESA e examinadas no período 7 de dezembro de $1966-18$ de abril de 1967, segundo a localização do domicílio

\begin{tabular}{|c|c|c|c|c|c|c|c|c|c|}
\hline \multirow{3}{*}{$\begin{array}{c}\text { Localizacão } \\
\text { do } \\
\text { domicllio }\end{array}$} & \multirow{3}{*}{$\begin{array}{l}\text { Número de } \\
\text { criancas } \\
\text { examinadas }\end{array}$} & \multicolumn{8}{|c|}{$M$ ê $s$} \\
\hline & & \multicolumn{2}{|c|}{ Dezembro } & \multicolumn{2}{|c|}{ Jan./Fev. } & \multicolumn{2}{|c|}{ Marco } & \multicolumn{2}{|c|}{ Abril } \\
\hline & & N.o & $\%$ & N.O & $\%$ & N.o & $\%$ & N.o & $\%$ \\
\hline Urbana & 595 & 183 & 70,4 & 170 & 68,0 & 101 & 75,9 & 141 & 69,5 \\
\hline Rural & 251 & 77 & 29,6 & 80 & 32,0 & 32 & 24,1 & 62 & 30,5 \\
\hline Total & 846 & 260 & 100,0 & 250 & 100,0 & 133 & 100,0 & 203 & 100,0 \\
\hline
\end{tabular}


CANDEIAS, J. A. N. - Anticorpos fixadores de complemento para o virus respiratório sincicial e adenovirus. Rev. Saúde públ., S. Paulo, 2(1):44-67, jun. 1968.

Colheita dos espécimens de sangue Estes foram colhidos da polpa do dedo indicador, por picada com agulha esterilizada, tendo sido utilizada uma agulha para cada criança. Depois de feita a limpeza do dedo com álcool e após secagem completa, foi feito o lancetamento; o sangue obtido, por expressão, foi colhido numa tira de papel filtro ${ }^{(1)}$, do tipo usado para eletroforese, não tendo sido difícil distribuir o sangue de modo a obterem-se, no mínimo, três manchas por criança. Os espécimens de sangue colhidos segundo esta técnica, após secagem à temperatura ambiente, foram agrupados em pequenos livretos, cada um dos quais correspondia ao material obtido de 20 crianças e remetidos, dentro de uma semana, à Faculdade de Higiene e Saúde Pública de São Paulo, através da Companhia Paulista de Estradas de Ferro, tendo sido, uma vez recebidos, conservados a $4^{\circ} \mathrm{C}$, até ulterior exame. $\mathrm{O}$ total de espécimens obtidos foi conservado nestas condições entre 4 e 6 meses.

Preparação dos extratos - Para a extração do sangue do papel de filtro, por eluição, recortou-se cada mancha de modo a ocupar uma superfície de $4 \mathrm{~cm}^{2}$ e mergulhou-se êste fragmento em $0,25 \mathrm{ml}$ de uma solução salina tamponada $(\mathrm{NaCl}$ $0,15 \mathrm{M}$; fosfato $0,01 \mathrm{M} ; \mathrm{pH}=7,2$ ), em tubos de ensaio $12 \times 75$, mantendose na geladeira a $4^{\circ} \mathrm{C}$, de um dia para outro. No dia seguinte retirou-se o papel de filtro, obtendo-se um extrato que se considerava como correspondendo a uma diluição de sôro de $1: 8$, uma vez que cada $4 \mathrm{~cm}^{2}$ de papel de filtro, do tipo usado, absorve cêrca de $0,08 \mathrm{ml}$ de sangue ${ }^{(2)}$. Este material foi utilizado para as reações de fixação de complemento, destinadas a evidenciar anticorpos para o vírus respiratório sincicial e para adenovírus.

O material utilizado nas reações de inibição da hemaglutinação, destinadas à pesquisa de anticorpos para os vírus parainfluenza 1,2 e 3 , obteve-se seguindo a técnica anterior com uma ligeira modificação, para eliminar os inibidores inespecíficos da hemaglutinação: a eluição foi feita em $0,25 \mathrm{ml}$ de uma suspensão de caolin a $25 \%$, em salina tamponada ( $\mathrm{NaCl} 0,15 \mathrm{M}$; fosfato $0,01 \mathrm{M}$; $\mathrm{pH}=7,2)$, de um dia para outro, a $4^{\circ} \mathrm{C}$, depois do que se retirou o papel de filtro e se removeu o caolin por centrifugação a $2.500 \mathrm{RPM}$, durante $20 \mathrm{mi}$ nutos. 0 - sobrenadante considerava-se como correspondendo a uma diluição de sôro de 1:8. Em virtude da diluição inicial ser, obrigatòriamente, mais elevada, situação que não nos interessava explorar, não utilizamos o RDE para a remoção de inibidores inespecíficos. 0 tratamento pelo caolin, em certos casos tem tendência a remover, também, anticorpos específicos (SCHMidT, LeNNETTE \& KING $\left.{ }^{74}, 1966\right)$, no entanto, consideramos esta técnica de maior utilidade, em nosso estudo, apesar daquele inconveniente.

Reação de fixação do complemento A técnica utilizada segue as normas estabelecidas por BRADSTREeT \& TAYLOR ${ }^{6}$ (1962), com algumas modificações: o volume final da reação, de $0,5 \mathrm{ml}$, foi completado pela mistura de $0,1 \mathrm{ml}$ de cada diluição do sôro a examinar, $0,1 \mathrm{ml}$ da dose ótima de antígeno, $0,1 \mathrm{ml}$ da diluição do complemento contendo 2 unidades $\mathrm{C}^{\prime} \mathrm{H}_{100}$ e $0,2 \mathrm{ml}$ de uma suspensão a $2 \%$ de hemácias de carneiro sensibilizadas.

$\mathrm{Na}$ reação foi usada a solução salina tamponada já descrita anteriormente, a propósito da obtenção dos extratos que, como dissemos, considerávamos equivalentes a uma diluição de sôro a 1:8. Os extratos foram inativados a $56^{\circ} \mathrm{C}$ durante 30 minutos e centrifugados a 2.500 RPM durante 15 minutos, com o que se obteve um sobrenadante líquido, utilizado no preparo de diluiçôes consecutivas,

(1) CARL SCHLEICHER \& SCHOL Co. n.o 2043.

(2) CANDEIAS, J. A. N. - Dados inéditos. 
CANDEIAS, J. A. N. - Anticorpos fixadores de complemento para o vírus respiratório sincicial e adenovirus. Rev. Saúde públ., S. Paulo, 2(1):44-67, jun. 1968.

com fator 2, na própria placa de aglutinação do tipo padronizado pela OMS.

A dose ótima de antígeno foi encontrada por "titulação em bloco", contra o respectivo sôro padrão, sendo definida como a dose capaz de revelar a menor quantidade de anticorpos.

A diluição do complemento com 2 unidades $\mathrm{C}^{\prime} \mathrm{H}_{\mathbf{1 0 0}}$ foi encontrada por “titulação em bloco" frente ao sôro hemolítico. Com esta titulação obteve-se, também, a dose ótima de hemolisina que consideramos como a dose capaz de ocasionar maior lise com a mais alta diluição do complemento. Uma unidade $\mathrm{C}^{\prime} \mathbf{H}_{100}$ de complemento é a diluição que dá $100 \%$ de hemólise frente à dose ótima de hemolisina.

O complemento utilizado na reação foi preservado pelo método de RichaRDson ${ }^{70}$ (1941). Quando conservado a $4^{\circ} \mathrm{C}$ pode manter-se aproximadamente por 1 ano (BRAdSTREeT \& TAYLOR $^{6}$, 1962), mas em nossas reações sua preparação foi feita mensalmente. Como o complemento preservado por aquêle método é hipertônico, a diluição teve de ser feita com salina e água destilada, nas seguintes proporções: para cada $0,1 \mathrm{ml}$ de complemento utilizavam-se $0,7 \mathrm{ml}$ de água destilada e um volume $\mathrm{V}$ de salina que variava conforme a diluição desejada. Este volume pode obter-se da fórmula

$$
\mathrm{V}=\frac{\left(\mathrm{dc}^{\prime}-10\right) 8}{100}
$$

em que $d c^{\prime}$ é a recíproca da diluição do complemento desejada.

A suspensão de hemácias de carneiro a $2 \%$ foi sensibilizada com a dose ótima de hemolisina, em partes iguais.

Foram incluídos na reação os controles de sôro, de antígenos, de hemácias e de complemento, êste último preparado com diluições contendo $2 \mathrm{C}^{\prime} \mathrm{H}_{100}, \mathbf{1 C}^{\prime} \mathrm{H}_{100}$ e $1 / 2 \mathrm{C}^{\prime} \mathrm{H}_{100}$.

Reação de inibição da hemaglutinação - Esta reação foi executada seguindo o método de SEver ${ }^{73}$ (1962), com algumas modificações (APHA ${ }^{1}, 1964$ ), utilizando-se o conjunto microtitulador de Takatsy (TAKATSY ${ }^{80}$ ).

A solução salina tamponada, já referi$\mathrm{da}$, foi o diluente utilizado na reação.

Com o extrato de cada um dos espécimens de sangue foram feitas diluições seriadas, com fator 2 , e a cada uma delas foram adicionados $0,025 \mathrm{ml}$ de cada um dos antígenos, parainfluenza 1,2 e 3 , tendo êstes sido diluídos de modo a conter, naquele volume, 4 unidades hemaglutinantes. As misturas sôro-vírus foram incubadas, à temperatura ambiente, durante 60 minutos, depois do que se adicionaram, a cada uma, $0,025 \mathrm{ml}$ de uma suspensão a $0,8 \%$ de hemácias humanas do grupo $O$. A leitura dos resultados foi feita após manutenção das rereferidas misturas à temperatura ambiente, durante 90 minutos.

Foram incluídos na reação os controles de sôro, de hemácias e de vírus, êste último com a finalidade de poder confirmar-se que estavam sendo usadas, na reação, 4 unidades hemaglutinantes.

Amostras padrões do virus e soros As amostras padrōes de vírus respiratório sincicial, adenovírus e vírus parainfluenza tipos 1, 2 e 3 , bem como de soros especficos foram fornecidas pela Dra. M. S. Pereira, de "Virus Reference Laboratory - Central Public Health Laboratories, Colindale", Londres. A amostra pàdrão de vírus respiratório sincicial utilizada foi a cêpa Long, com passagens múltiplas em células $\mathrm{HeLa}$, nas quais ocasiona um efeito citopático típico, que se estende a cêrca de $75 \%$ da camada celular, em culturas de células preparadas em tubos $16 \times 150$, ao fim de 5 dias. A amostra padrão de adenovírus utilizada foi a cêpa padrão do tipo 5 Sub. 5 U.S.A. - com passagens multiplas em cultura de células HeLa, nas quais ocasiona um efeito citopático típico, que se estende a cêrca de $75 \%$ da camada celular, em culturas de células 
CANDEIAS, J. A. N. - Anticorpos fixadores de complemento para o vírus respiratório sincicial e adenovirus. Rev. Saúde públ., S. Paulo, 2(1):44-67, jun. 1968.

preparadas em tubos $16 \times 150$, ao fim de 3.4 dias. A amostra padrão de vírus parainfluenza $l$ utilizada, foi uma cêpa com 6 passagens em culturas de rim de macaco rhesus e 4 passagens em culturas de rim embrionário humano; a amostra padrão de vírus parainfluenza 3 utilizada foi uma cêpa com 4 passagens em cultura de rim embrionário humano.

Preparação dos antígenos - 0 antígeno de vírus respiratório sincicial, destinado à reação de fixação do complemento, foi obtido em culturas de células $\mathrm{HeLa}$, preparadas em tubos $16 \times 150$, usando-se como meio de crescimento um meio com $20 \%$ de sôro inativado de vitela, $0,5 \%$ de hidrolisado de lactalbumina e $79,5 \%$ de solução salina de Hanks, adicionado de penicilina e estreptomicina na concentração final de 200 unidades por ml. Antes de inoculados os tubos de cultura com a amostra de vírus padrão, as culturas eram lavadas com solução salina de Hanks, contendo penicilina e estreptomicina na concentração final de 200 unidades por ml. Cada tubo era então inoculado com $0,2 \mathrm{ml}$ da amostar padrão de vírus e $0,8 \mathrm{ml}$ de meio de manutenção constituído por $0,5 \%$ de hidrolisado de lactalbumina e $99,5 \%$ de solução salina de Hanks, com penicilina e estreptomicina na concentração final de 200 unidades por $\mathrm{ml}$. As culturas infectadas eram incubadas a $37^{\circ} \mathrm{C}$ até o momento em que se notava um efeito citopático mais acentuado, quando se congelavam e descongelavam, por três vêzes, constituindo o líquido de cultura com restos celulares, o antígeno utilizado, após inativação a $56^{\circ} \mathrm{C}$, durante 30 minutos.

Para a obtenção do antígeno de adenovírus utilizado na reação de fixação de complemento prepararam-se culturas de células HeLa, usando o meio de crescimento referido acima. Cada tubo era inoculado com $0,2 \mathrm{ml}$ da amostra padrão de adenovírus tipo 5 e $0,8 \mathrm{ml}$ do já mencionado meio de manutenção. As culturas infectadas eram incubadas a $37^{\circ} \mathrm{C}$ até aparecimento de efeito citopático máximo. 0 líquido de cultura com restos celulares constituia o antígeno, após inativação a $56^{\circ} \mathrm{C}$ durante 30 minutos, sem se recorrer ao congelamento e descongelamento múltiplo.

Os antígenos de vírus parainfluenza 1 , 2 e 3 , utilizados na reação de inibição da hemaglutinação foram preparados em culturas primárias de rim de macaco rhesus. Estas culturas são recebidas em meio de manutenção Melnick $A$, com sôro anti-SV 5 na concentração de $0,2 \%$. $^{\text {(1) }}$ Antes de inoculadas, eram lavadas com solução salina de Hanks, contendo penicilina e estreptomicina na concentração final de 200 unidades por ml. Cada tubo de cultura era inoculado com $0,2 \mathrm{ml}$ da amostra padrão de vírus e $0,8 \mathrm{ml}$ de meio 199, com penicilina e estreptomicina na concentração final de 200 unidades por ml. As culturas infectadas eram incubadas a $33^{\circ} \mathrm{C}$ até o efeito citopático máximo. A titulação por hemadsorção com uma suspensão de hemácias de cobaia a $0,4 \%$, após incubação durante 20 minutos a $4^{\circ} \mathrm{C}$, deu, regularmente, títulos maiores que $10^{6} \mathrm{TCD}_{50}$ para os vírus parainfluenza 1 e 2 e da ordem de $10^{5,5}$ $\mathrm{TCD}_{50}$, para o vírus parainfluenza 3 . As culturas congeladas e descongeladas por três vêzes, constituiam o antígeno utilizado na reação.

\section{RESULT A D O}

A distribuição dos soros positivos para o vírus respiratório sincicial e adenovírus, em função da idade, nas 972 crianças examinadas, é apresentada na Tabela 5. Obtiveram-se porcentagens de positividade de $21,5 \%, 19,6 \%, 30,3 \%$ e $44,4 \%$ correspondentes, respectivamente, aos grupos etários de 3 a 6 meses, 7 a 11 meses, 1 a 6 anos e 7 a 14 anos, no

(1) Flow Laboratories Inc., U.S.A. 
CANDEIAS, J. A. N. - Anticorpos fixadores de complemento para o vírus respiratório sincicial e adenovirus. Rev. Saude pübl., S. Paulo, 2(1):44-67, jun. 1968.

caso do vírus respiratório sincicial; para os adenovírus, semelhante distribuição apresenta os valores $24,6 \%, 22,9 \%$, $53,5 \%$ e $48,5 \%$. Englobando tôdas as idades, daquele total, 337 soros foram positivos para o vírus respiratório sincicial $(34,6 \%)$ e 464 soros mostraram-se positivos para adenovírus $(47,7 \%)$.

Na Tabela 6 apresentamos a distribuição porcentual das crianças estudadas, conforme os títulos de anticorpos fixadores de complemento e por grupo etário.
No grupo de idade inferior a 1 ano, de um total de 26 soros positivos para o vírus respiratório sincicial, $88,5 \%$ distribuem-se na faixa de títulos 8 e 16 e os $11,5 \%$ restantes pelos títulos iguais ou superiores a 32 ; já no grupo de 1 a 14 anos estas porcentagens foram, respectivamente, de $79,7 \%$ e $20,3 \%$, num total de 311 soros positivos. Dos 30 soros positivos para adenovírus, no grupo de idade inferior a 1 ano, $83,4 \%$ possuiam títulos de 8 e 16 e $16,6 \%$ títulos iguais ou superiores a 32 ; nas 434 crianças

T A B ELA 5

Distribuição dos soros positivos para o vírus respiratório sincicial e adenovírus, segundo a idade, em 972 criancas examinadas

\begin{tabular}{|c|c|c|c|c|c|}
\hline \multirow{3}{*}{ Grupo etário } & \multirow{3}{*}{$\begin{array}{c}\text { Número } \\
\text { de soros } \\
\text { examinados }\end{array}$} & \multicolumn{4}{|c|}{ Soros Positivos (1) } \\
\hline & & \multicolumn{2}{|c|}{$\begin{array}{l}\text { Vírus respiratório } \\
\text { sincicial }\end{array}$} & \multicolumn{2}{|c|}{ Adenovírus } \\
\hline & & N.o & $\%$ & N.o & $\%$ \\
\hline $31-16$ meses & 65 & 14 & 21,5 & 16 & $\mathbf{2 4 , 6}$ \\
\hline $7|-| 11$ meses & 61 & 12 & 19,6 & 14 & 22,9 \\
\hline $1-16$ anos & 461 & 140 & 30,3 & 247 & 53,5 \\
\hline $71-\mid 14$ anos & 385 & 171 & 44,4 & 187 & 48,5 \\
\hline Total & 972 & $\mathbf{3 3 7}$ & 34,6 & 464 & 47,7 \\
\hline
\end{tabular}

(1) Soros de título $\supseteq 8$.

TABELA 6

Distribuição porcentual das crianças estudadas, segundo o título de anticorpos fixadores de complemento para o virus respiratório sincicial e adenoviruos e segundo o grupo etário

\begin{tabular}{|c|c|c|c|}
\hline $\begin{array}{l}\text { Grupo etário } \\
\text { (anos) }\end{array}$ & Titulo & $\begin{array}{c}\text { Virus respiratório } \\
\text { sincicial }\end{array}$ & Adenovírus \\
\hline \multirow{3}{*}{$<$} & $8|-| 16$ & $88,5 \%$ & $83,4 \%$ \\
\hline & $\supseteq \quad 32$ & $11,5 \%$ & $16,6 \%$ \\
\hline & & $100,0 \%$ & $100,0 \%$ \\
\hline Total & & (26) & (30) \\
\hline \multirow{3}{*}{$1|-| 14$} & $8|-| 16$ & $79,7 \%$ & $83,6 \%$ \\
\hline & $\geq 32$ & $20,3 \%$ & $16,4 \%$ \\
\hline & & $100,0 \%$ & $100,0 \%$ \\
\hline Total & & (311) & (434) \\
\hline
\end{tabular}


CANDEIAS, J. A. N. - Anticorpos fixadores de complemento para o vírus respiratório sincicial e adenovirus. Rev. Saúde públ., S. Paulo, 2(1):44-67, jun. 1968.

de idade compreendida entre 1 e 14 anos, com soros positivos para adenovírus, a distribuição é muito semelhante, com porcentagens de $83,6 \%$ e $16,4 \%$.

$\mathrm{Na}$ Tabela 7 apresentamos as diferentes porcentagens de positividade para o vírus respiratório sincicial e adenovírus, para um e outro sexo, em crianças menores de 1 ano e de idade superior a 1 ano. Pode observar-se que os indivíduos de sexo feminino apresentam porcentagens mais elevadas do que os de sexo masculino, da ordem de $22,4 \%$ contra $19,1 \%$ e $24,1 \%$ contra $23,5 \%$, nas crianças de idade inferior a 1 ano. No grupo de crianças de 1 a 14 anos evidencia-se uma discreta predominância do sexo feminino em relação ao masculino para o primeiro vírus referido, como indicam as porcentagens de $39,6 \%$ e $34,2 \%$, enquanto para os adenovírus êste predomínio se define no sexo masculino com a porcentagem de $53,2 \%$ contra $49,2 \%$.

Um estudo comparativo entre a localização do domicílio e as porcentagens de soros positivos para o vírus respiratório sincicial e adenovírus, leva aos resultados apresentados na Tabela 8 , onde as porcentagens de positividade para ambos os vírus são maiores na zona rural do que na zona urbana, em qualquer dos grupos etários, com valores de $22,2 \%$ e $20,2 \%$, em relação ao vírus respiratório sinci-

\section{TABELA 7}

Distribuição dos soros positivos para o vírus respiratório sincicial e adenovírus, segundo o sexo, em 972 crianças examinadas

\begin{tabular}{|c|c|c|c|c|c|c|}
\hline \multirow{3}{*}{$\begin{array}{c}\text { Grupo etário } \\
\text { (anos) }\end{array}$} & \multirow{3}{*}{ Sexo } & \multirow{3}{*}{$\begin{array}{c}\text { Número } \\
\text { de soros } \\
\text { examinados }\end{array}$} & \multicolumn{4}{|c|}{ Soros Positivos (1) } \\
\hline & & & \multicolumn{2}{|c|}{$\begin{array}{l}\text { Virus respiratório } \\
\text { sincicial }\end{array}$} & \multicolumn{2}{|c|}{ Adenovirus } \\
\hline & & & N.o & $\%$ & N.o & $\%$ \\
\hline \multirow{2}{*}{$<1$} & Masc. & 68 & 13 & 19,1 & 16 & 23,5 \\
\hline & Fem. & 58 & 13 & 22,4 & 14 & 24,1 \\
\hline \multirow[b]{2}{*}{$1|-| 14$} & Masc. & 458 & 157 & 34,2 & 243 & 53,2 \\
\hline & Fem. & 388 & 154 & 39,6 & 191 & 49,2 \\
\hline Total & & 972 & 337 & 34,6 & 464 & 47,7 \\
\hline
\end{tabular}

(1) Soros de titulo $\geqslant 8$.

TABELA 8

Distribuição dos soros positivos para o vírus respiratório sincicial e adenovírus, segundo a localização do domicílio, em 972 crianças examinadas

\begin{tabular}{|c|c|c|c|c|c|c|}
\hline \multirow{3}{*}{$\begin{array}{l}\text { Irupo etário } \\
\text { (anos) }\end{array}$} & \multirow{3}{*}{$\begin{array}{c}\text { Localização } \\
\text { do } \\
\text { domicílio }\end{array}$} & \multirow{3}{*}{$\begin{array}{c}\text { Número } \\
\text { de soros } \\
\text { examinados }\end{array}$} & \multicolumn{4}{|c|}{ Soros Positivos (1) } \\
\hline & & & \multicolumn{2}{|c|}{$\begin{array}{c}\text { Virus respiratório } \\
\text { sincicial }\end{array}$} & \multicolumn{2}{|c|}{ Adenovirus } \\
\hline & & & N.o & $\%$ & N.o & $\%$ \\
\hline \multirow{2}{*}{$<1$} & Urbana & 99 & 20 & 20,2 & 23 & 23,2 \\
\hline & Rural & 27 & 6 & 22,2 & 7 & 25,9 \\
\hline \multirow{2}{*}{$1|-| 14$} & Urbana & 595 & 192 & 32,2 & 246 & 41,3 \\
\hline & Rural & 251 & 119 & 47,4 & 188 & 74,9 \\
\hline Total & & 972 & 337 & 34,6 & 464 & 47,7 \\
\hline
\end{tabular}

(1) Soros de título $\supseteq 8$. 
CANDEIAS, J. A. N. - Anticorpos fixadores de complemento para o virus respiratório sincicial e adenovirus. Rev. Saude puibl., S. Paulo, 2(1):44-67, jun. 1968.

cial e $25,9 \%$ e $23,2 \%$ para os adenovírus, em crianças de idade inferior a 1 ano; nas crianças cuja idade variava entre 1 e 14 anos, aquelas porcentagens foram, respectivamente, $47,4 \%$ e $32,2 \%$ e $74,9 \%$ e $41,3 \%$.

A distribuição dos soros positivos para os vírus parainfluenza dos tipos 1,2 e 3 , segundo a idade, é apresentada na Tabela 9. Obtiveram-se porcentagens de positividade de $46,1 \%, 32,7 \%, 41,8 \%$, $55,1 \%$ para os grupos etários de 3 a 6 meses, 7 a 11 meses, 1 a 6 anos e 7 a 14 anos, no caso do vírus parainfluenza do tipo 1; para o tipo 2, estas porcentagens foram respectivamente de $44,6 \%$, $40,9 \%, 48,3 \%$ e $64,6 \%$; em relação ao tipo 3 , obtiveram-se as seguintes porcentagens distribuídas pelos grupos etários referidos: $53,8 \%, \quad 37,7 \%, 59,8 \%$ e $81,5 \%$. Considerando o conjunto de tôdas as idades, do total de 972 crianças examinadas, 455 mostraram-se positivas para o vírus parainfluenza $1(46,8 \%)$, 526 para o parainfluenza $2(54,1 \%)$ e 648 para o parainfluenza $3(66,6 \%)$.

Na Tabela 10 podem comparar-se as porcentagens de positividade, conforme

T A B EL A 9

Distribuição dos soros positivos para os virus parainfluenza 1,2 e 3 , segundo a idade, em 972 crianças examinadas

\begin{tabular}{|c|c|c|c|c|c|c|c|}
\hline \multirow{3}{*}{ Grupo etário } & \multirow{3}{*}{$\begin{array}{c}\text { Número } \\
\text { de soros } \\
\text { examinados }\end{array}$} & \multicolumn{6}{|c|}{ Soros Positivos (1) } \\
\hline & & \multicolumn{2}{|c|}{ Parainfluenza 1} & \multicolumn{2}{|c|}{ Parainfluenza 2} & \multicolumn{2}{|c|}{ Parainfluenza 3} \\
\hline & & N.o & $\%$ & N.O & $\%$ & N.O & $\%$ \\
\hline $3 \mid-16$ meses & 65 & 30 & 46,1 & 29 & 44,6 & 35 & 53,8 \\
\hline 7 -| 11 meses & 61 & 20 & 32,7 & 25 & 40,9 & 23 & 37,7 \\
\hline $11-16$ anos & 461 & 193 & 41,8 & 223 & 48,3 & 276 & 59,8 \\
\hline 7 -| 14 anos & 385 & 212 & 55,1 & $249^{\circ}$ & 64,6 & 314 & 81,5 \\
\hline Total & 972 & 455 & 46,8 & 526 & 54,1 & 648 & 66,6 \\
\hline
\end{tabular}

(1) Soros de títujo $\geq 16$

TAB E L A 10

Distribuição porcentual das crianças estudadas, segundo o título de anticorpos inibidores da hemaglutinação para os vírus parainfluenza 1,2 e 3 e segundo o grupo etário

\begin{tabular}{|c|c|c|c|c|}
\hline \multirow{2}{*}{$\begin{array}{l}\text { Grupo etário } \\
\text { (anos) }\end{array}$} & \multirow{2}{*}{ Título } & \multicolumn{3}{|c|}{$v i r u s$} \\
\hline & & Parainfluenza 1 & Parainfluenza 2 & Parainfluenza 3 \\
\hline & $16|-| \quad 32$ & $64,0 \%$ & $48,1 \%$ & $31,1 \%$ \\
\hline \multirow[t]{3}{*}{$<1$} & $64|-| 128$ & $34,0 \%$ & $46,3 \%$ & $51,7 \%$ \\
\hline & 256 & $2,0 \%$ & $5,6 \%$ & $17,2 \%$ \\
\hline & & $100,0 \%$ & $100,0 \%$ & $100,0 \%$ \\
\hline \multirow[t]{2}{*}{ Total } & & $(\mathbf{5 0 )}$ & $(\mathbf{5 4})$ & $(58)$ \\
\hline & $16|-| 32$ & $87,4 \%$ & $57,2 \%$ & $28,3 \%$ \\
\hline \multirow[t]{3}{*}{$1-14$} & $64|-| 128$ & $10,1 \%$ & $39,4 \%$ & $61,4 \%$ \\
\hline & 256 & $2,5 \%$ & $3,4 \%$ & $10,3 \%$ \\
\hline & & $100,0 \%$ & $100,0 \%$ & $100,0 \%$ \\
\hline Total & & $(405)$ & $(472)$ & $(590)$ \\
\hline
\end{tabular}


CANDEIAS, J. A. N. - Anticorpos fixadores de complemento para o virus respiratório sincicial e adenovirus. Rev. Saúde pübl., S. Paulo, 2(1):44-67, jun. 1968.

os títulos inibidores da hemaglutinação, por grupo etário. No grupo etário de menores de 1 ano, as porcentagens de positividade para o vírus parainfluenza 1 tomam os valores $64,0 \%$ nos títulos 16 a $32,34,0 \%$, nos títulos 64 a 128 e sòmente $2,0 \%$ com título de 256. Para os vírus dos tipos 2 e 3 as respectivas porcentagens são, $48,1 \%$ e $31,1 \% ; 46,3 \%$ e $51,7 \% ; 5,6 \%$ e $17,2 \%$. Analisando o que se passa no grupo etário de 1 a 14 anos, para os virus parainfluenza 1 , 2 e 3 e em relação às faixas de títulos referidas, as porcentagens obtidas são:
$87,4 \%, 10,1 \%$ e $2,5 \% ; 57,2 \%, 39,4 \%$ e $3,4 \% ; 28,3 \%, 61,4 \%$ e $10,3 \%$.

$\mathrm{Na}$ Tabela 11 pode ver-se que, tanto em relação ao grupo de crianças de idade inferior a 1 ano, como ao grupo de 1 a 14 anos, as porcentagens de positividade são mais acentuadas nos indivíduos de sexo masculino, com valores de $51,4 \%$ para o vírus parainfluenza 1 , $50,0 \%$ para o vírus parainfluenza 2 e $51,4 \%$ para o vírus parainfluenza 3 , contra $25,8 \%, 34,4 \%$ e $39,6 \%$ nas crianças do sexo feminino, no primeiro grupo etário. No grupo de 1 a 14 anos aquê-

TA BELA 11

Distribuição dos soros positivos para os virus parainfluenza 1,2 e 3 , segundo o sexo, em 972 crianças examinadas

\begin{tabular}{|c|c|c|c|c|c|c|c|c|}
\hline \multirow{3}{*}{$\begin{array}{l}\text { Idade } \\
\text { (em anos) }\end{array}$} & \multirow{3}{*}{ Sexo } & \multirow{3}{*}{$\begin{array}{l}\text { Número } \\
\text { de soros } \\
\text { examinados }\end{array}$} & \multicolumn{6}{|c|}{ Soros Positivos ( $\left.{ }^{(}\right)$} \\
\hline & & & \multicolumn{2}{|c|}{ Parainfluenza 1} & \multicolumn{2}{|c|}{ Parainfluenza 2} & \multicolumn{2}{|c|}{ Parainfluenza $\mathbf{3}$} \\
\hline & & & N.o & $\%$ & N.o & $\tau_{C}$ & N.0 & $\ddot{i c}$ \\
\hline \multirow{2}{*}{$<1$} & Masc. & 68 & 35 & 51,4 & 34 & 50,0 & 35 & 51,4 \\
\hline & Fem. & 58 & 15 & 25,8 & 20 & 34,4 & 23 & 39,6 \\
\hline \multirow{2}{*}{$1-14$} & Masc. & 458 & 281 & 61,3 & 308 & 67,2 & 377 & 82,3 \\
\hline & Fem. & 388 & 124 & 31,9 & 164 & 42,2 & 213 & 54,8 \\
\hline Total & & 972 & 455 & 46,8 & 526 & 54,1 & 648 & 66,6 \\
\hline
\end{tabular}

(1) Soros de titulo $\geq 16$.

TABELA 12

Distribuição dos soros positivos para os virus parainfluenza 1, 2 e 3 , segundo a localização do domicillio, em 972 crianças examinadas

\begin{tabular}{|c|c|c|c|c|c|c|c|c|}
\hline \multirow{3}{*}{$\begin{array}{c}\text { Idade } \\
\text { (em anos) }\end{array}$} & \multirow{3}{*}{$\begin{array}{c}\text { Localização } \\
\text { do } \\
\text { domicílio }\end{array}$} & \multirow{3}{*}{$\begin{array}{l}\text { Número } \\
\text { de soros } \\
\text { exami- } \\
\text { nados }\end{array}$} & \multicolumn{6}{|c|}{ Soros Positivos (1) } \\
\hline & & & \multicolumn{2}{|c|}{ Parainfluenza 1} & \multicolumn{2}{|c|}{ Parainfluenza 2} & \multicolumn{2}{|c|}{ Parainfluenza 3} \\
\hline & & & N.o & $c_{0}$ & N.o & $\%_{\%}$ & N.o & $\%$ \\
\hline \multirow{2}{*}{$<1$} & Urbana & 99 & 40 & 40,4 & 45 & 45,4 & 47 & 47,4 \\
\hline & Rural & 27 & 10 & 37,1 & 9 & $\mathbf{3 3 , 3}$ & $\mathbf{1 1}$ & 40,7 \\
\hline \multirow{2}{*}{$1|-| 14$} & Urbana & 595 & 293 & 49,2 & 351 & 58,9 & 419 & 70,4 \\
\hline & Rural & 251 & 112 & 44,6 & 121 & $4 \delta, 2$ & 171 & 68,1 \\
\hline Total & & 972 & 455 & 46,8 & 526 & 54,1 & 648 & 66,6 \\
\hline
\end{tabular}

(1) Soros de título $\geqslant 16$. 
CANDEIAS, J. A. N. - Anticorpos fixadores de complemento para o virus respiratório sincicial e adenovirus. Rev. Saúde públ., S. Paulo, 2(1):44-67, jun. 1968.

les valores porcentuais foram, respectivamente, $61,3 \%$ e $31,9 \%$ para o vírus parainfluenza $1,67,2 \%$ e $42,2 \%$ para o vírus parainfluenza 2 e $82,3 \%$ e $54,8 \%$ para o vírus parainfluenza 3 .

Analisando na Tabela 12 a distribuição das porcentagens de soros positivos para o vírus parainfluenza 1,2 e 3 , nas zonas urbana e rural, pode observar-se uma aparente predominância da zona urbana sôbre a zona rural, por fôrça dos seguintes valores: no grupo etário de idade inferior a 1 ano, $40,4 \%$ e $37,1 \%$ para o vírus parainfluenza $1,45,4 \%$ e $33,3 \%$ para o vírus parainfluenza 2 , $47,4 \%$ e $40,7 \%$ para o vírus parainfluenza 3. No grupo etário de 1 a 14 anos, $49,2 \%$ e $44,6 \%$ para o vírus parainfluenza $1,58,9 \%$ e $48,2 \%$ para o vírus parainfluenza $2 \mathrm{e}$, finalmente, $70,4 \%$ e $68,1 \%$ para o vírus parainfluenza 3 .

\section{S CUS SAO}

0 emprêgo da reação de inibição da hemaglutinação, feita segundo técnica que utiliza quantidades mínimas de sôro, da ordem de $0,025 \mathrm{ml}$, e da reação de fixação do complemento feita em placas de aglutinação, permitiu-nos estudar a distribuição de anticorpos inibidores da hemaglutinação para os vírus parainfluenza 1,2 e 3 e de anticorpos fixadores de complemento para o virus respiratório sincicial e adenovírus, num extenso número de crianças. Estudos feitos por outros autores demonstraram a utilidade destas técnicas (BEEM et alii ${ }^{3}$, 1960; Bruno-Lôbo, Pereira \& PereiRA $^{9}$, 1961; SEVER ${ }^{75}$, 1962; HsIUNG, ISACSON \& TUCKER ${ }^{43}$, 1963; HORNSLETH \& Volkert ${ }^{42}$, 1964; Candeias \& Chrisovão ${ }^{11}$, 1966; GWaltney ${ }^{39}$, 1966).

Utilizamos ainda a técnica de colheita de sangue, por embebição em papel de filtro, com o que se podem obter quantidades de sangue da ordem de $0,08 \mathrm{ml}$; após eluição obtêm-se extratos correspondentes a uma diluição inicial de sôro de 1:8. Esta técnica já foi sufi- cientemente estudada e utilizada por diversos autores, provando ser de particular valor, não só do ponto de vista de conservação do material, como também em têrmos da colheita, menos espetacular e dolorosa do que a venopunctura. Êste último aspecto não é para desprezar-se em pediatria (K KLTER $^{51}, 1963$; Brody et alii ${ }^{8}$, 1964; Worth ${ }^{\text {s9, }}$ 1964; Chin et alii ${ }^{21}$, 1966; Souza \& CamarGO $\left.^{78}, 1966\right)$.

Apresentamos a discussão dos resultados obtidos com as referidas técnicas, em relação aos atributos escolhidos.

Distribuição dos anticorpos segundo a idade - Depois do desaparecimento dos anticorpos maternos para o vírus respiratório sincicial (McCleLLAND et alii ${ }^{\overline{5} 8}$, 1961; Moss, Adams \& Tobins ${ }^{61}, 1963$ ), apesar de ocorrer um aumento nos títulos fixadores de complemento, as porcentagens de positividade até os 2 anos de vida não são muito elevadas, conforme as observações de McClellan et alii ${ }^{58}$ (1961), que encontraram, no grupo de 6 a 11 meses, sòmente $6 \%$ com anticorpos para aquêle vírus e no grupo de 1 ano de idade, uma porcentagem de positividade de $16 \%$. Hambling ${ }^{40}$ (1964) refere-se a porcentagens de positividade de $38 \%$ em crianças de 1 a 2 anos e $56 \%$ a $93 \%$ em crianças de 4 anos. Saliba, Glezen \& Chin ${ }^{73}$ (1967) também se referem à presença de anticorpos para o vírus respiratório sincicial em 97\% das crianças de 5 anos e idade superior.

As infecções pelo vírus respiratório sin. cicial ocorrem, principalmente, em crianças de idade compreendida entre 1 e 2 anos e, em virtude das múltiplas infecções subseqüentes, como já vimos, a grande maioria das crianças de mais idade possui anticorpos circulantes. Esta situação tende a produzir epidemias anuais nos grupos mais jovens suscetíveis e surtos não epidêmicos nos indivíduos de maior idade (Jamieson, Alexandre \& TEAL $\left.{ }^{46}, 1966\right)$. 
CANDEIAS, J. A. N. - Anticorpos fixadores de complemento para o virus respiratório sincicial e adenovirus. Rev. Saúde públ., S. Paulo, 2(1):44-67, jun. 1968.

Nossos resultados revelaram que $20,7 \%$ das crianças examinadas, com idade inferior a 1 ano, possuem anticorpos fixadores de complemento para o vírus respiratório sincicial, em título igual ou superior a 8 , porcentagem bem mais elevada do que as já referidas, se levarmos em consideração que os autores aceitam como positivos os soros de título igual ou superior a 4. Por outro lado, analisando, separadamente, as porcentagens de positividade para os grupos etários de 3 a 6 meses e 7 a 11 meses, encontram-se valores de $21,5 \%$ e $19,7 \%$. Um teste de proporções ao nível de $1 \%$, aplicado a êstes valores, leva a um resultado segundo o qual não é estatisticamente significativa a diferença entre as referidas porcentagens. Para um grande número de viroses respiratórias, cêrca dos 6 meses de idade processa-se a queda de anticorpos de origem materna, à qual se segue a elevação resultante dos primeiros contactos com o agente infeccioso. O não encontro, em nossos resultados, de uma queda significativa nos títulos de anticorpos poderia sugerir um contacto precoce, das crianças estudadas, com o vírus respiratório sincicial, uma vez que as infecções por êste vírus costumam ocorrer, mais freqüentemente, entre o primeiro e segundo ano de vida (GARDNER, ELDERKIN \& W $_{\text {ALL }}{ }^{32}, 1964$ ). A êste respeito não devem deixar de considerar-se os resultados das experiências feitas em animais e as observações de casos patológicos humanos, segundo os quais o organismo fetal é capaz de produzir anticorpos (SILverstein et alii ${ }^{7 t}$, 1963; Fudenberg \& Fudenberg $^{31}$, 1964; Buffe \& Burtin 10, 1967).

Já a porcentagem de $36,7 \%$ de soros positivos que encontramos no grupo de crianças de 1 a 14 anos, é um pouco mais baixa do que a referida por alguns autores (McClelland et alii ${ }^{58}, 1961$; GardNer, Elderkin \& Wall ${ }^{52}, 1964$; WEIBEL et alii ${ }^{87}, 1966$ ). Mesmo considerando êste grupo subdividido nos grupos etários de 1 a 6 anos e 7 a 14 anos, as respectivas porcentagens de positivi- dade, $30.3 \%$ e $44,4 \%$ se mostram mais baixas. No entanto, quando submetidas a teste de proporções é significativa a diferença entre elas, devendo a elevação corresponder ao aumento dos níveis de anticorpos que se processa com o decorrer da idade (Pereira, Bruno-Lôbo \& Pereira ${ }^{63}$, 1961; Doggert ${ }^{28}$, 1965; Candeias \& Christovão ${ }^{11}$, 1966; Candeias \& Himelfarb ${ }^{12}, 1966$; JaMieson, Alexander \& Teal $\left.{ }^{46}, 1966\right)$.

No grupo de crianças examinadas parecem ter sido freqüentes as infecções pelo vírus respiratório sincicial, durante o período de maior susceptibilidade, mas os contactos subseqüentes com o agente etiológico não parecem ter tido a mesma intensidade dada a lenta elevação das porcentagens de positividade. Mesmo as porcentagens observadas nos grupos etários de 7 a 11 meses e de 1 a 6 anos, respectivamente, com valores de $19,6 \%$ e $30,3 \%$, não se mostram diferentes quando analisadas estatissticamente ao nível já referido. Estas observações sôbre a relação entre anticorpos circulantes e reinfecção pelo vírus respiratório sincicial, devem, no entanto, ser devidamente criticadas em virtude das recentes observaçōes de Coates et alii ${ }^{2: 2}$ (1966) e de PIKE ${ }^{65}$ (1967). Mais do que os anticorpos circulantes parecem ser importantes nas infecções e reinfecções pelo vírus respiratório sincicial, como por outros vírus respiratórios (SMITH et alii ${ }^{77}, 1966$; Leading ARTicles ${ }^{56}, 1967$ ), os anticorpos ao nível da mucosa nasal (BEEM ${ }^{3}$, 1967). Nós mesmos tivemus oportunidade de isolar o vírus respiratório sincicial de uma criança com a idade de 45 dias, gravemente enfêrma com uma síndrome de bronquiolite aguda, não tendo, no entanto, sido possivel pesquisar os anticorpos circulantes de origem materna (CANDEIAS ${ }^{12 a}$, 1967).

Em relação ao vírus respiratório sincicial, como pode verificar-se pelos resultados obtidos, não são muito freqüientes os títulos superiores a 32, cujo total corresponde a uma porcentagem de $11,5 \%$; 
CANDEIAS, J. A. N. - Anticorpos fixadores de complemento para o virus respiratório sinciclal e adenovírus. Rev. Saúde públ., S. Paulo, 2(1):44-67, jun. 1968.

a grande maioria, $88,5 \%$, encontra-se ao nível dos títulos 8 e 16, distribuição também observada por Doggett ${ }^{28}$ (1965) em soros provenientes de várias partes do mundo. A êste respeito CHanock \& Finberg ${ }^{15}$ (1957) e Berglund, Vihma \& Wickström ${ }^{5}$ (1965) sugerem que se inicie a titulação com a diluição $1: 2$ ou $1: 4$, no sentido de se evidenciar maior número de soros positivos, dada a possível insensibilidade da reação de fixação de complemento em soros de crianças muito jovens. Dentro dêste critério, as porcentagens de positividade que obteríamos, afastar-se-iam, ainda mais, dos valores encontrados por outros autores.

Numerosos inquéritos sorológicos sôbre os adenovírus demonstram que as infecções ocasionadas por êstes ocorrem nos primeiros anos de vida (Jordan et alii ${ }^{50}$, 1956; WeNner et alii ${ }^{88}, 1957$; JoRDAN, Badger \& Dingle ${ }^{49}, 1958$; Pereira \& McCallum ${ }^{64}$, 1964; Tosi et alii ${ }^{83}, 1964$ ). Com 5 anos de idade quase tôdas as crianças parecem ter sido infectadas, pelo menos, por um tipo de adenovírus e $50 \%$, pelo menos, por quatro tipos, parecendo contribuir como fator de susceptibilidade o estado de nutrição deficiente (VAN DER VEeN ${ }^{85}$, 1963).

Do mesmo modo que para o vírus respiratório sincicial, a queda nos títulos de anticorpos fixadores de complemento, de origem materna, começa a manifestar-se entre o quinto e o sexto mês de vida (JoRdan, BAdGer \& Dingle ${ }^{49}$, 1956; WenNer et alii ${ }^{88}, 1957$; PotTer \& Shedden ${ }^{68}, 1963$ ), sendo o seu declínio mais rápido do que o dos anticorpos neutralizantes.

Se considerarmos que os anticorpos fixadores de complemento são grupo-específicos (Ginsberg et alii ${ }^{35}$, 1965; HilleMAN et alii ${ }^{41}$, 1955; Rowe et alii ${ }^{72}$, 1955), a reação de fixação de comple. mento evidenciará uma experiência com maior número de tipos do que a neutra lização.

Por outro lado Parrote et alii ${ }^{62}$ (1961) acham que as porcentagens de positividade para anticorpos fixadores de complemento não devem corresponder à realidade, no grupo de crianças de idade inferior a 7 meses, pelo fato da reação de fixação de complemento perder certa sensibilidade. Portnoy et alii ${ }^{66}$ (1967) também chegam à conclusão de que a reação de fixação do complemento perde sua sensibilidade em crianças, talvez por resposta insuficiente de um sistema retículo-endotelial imaturo, ou por ausência de sensibilização prévia com o antígeno de grupo. Sugerem, mesmo, a complementação da referida reação pelas reações de neutralização ou inibição da hemaglutinação, a fim de a freqüência das infecções por adenovírus não ser subestimada. Se a estas observações jun. tarmos as de Wenner et alii ${ }^{88}$ (1957), que são de opinião que o aumento acentuado de anticorpos fixadores de complemento observado com a idade, pode estar relacionado com a capacidade que certos tipos têm de se difundir mais ou menos extensamente, e as de $K_{\text {ATZ }}$ et alii ${ }^{5^{\circ}}$ (1957) e Huebnner ${ }^{44}$ (1963), que se referem à desigual capacidade antigênica de certos tipos e GNesh ${ }^{36}$ (1965), que sugere a possivel interferência dos vírus da influenza com adenovírus, somos levados a concluir que os resultados de um inquérito sorológico, em têrmos de anticorpos fixadores de complemento para adenovírus, têm de ser muito cuidado. samente analisados.

No grupo de crianças de idade infe. rior a 1 ano a porcentagem de positividade por nós obtida foi de $23,8 \%$, valor nitidamente mais baixo do que o obtido por Carvalho ${ }^{13}$ (1960), que no grupo etário de 6 a 11 meses já refere porcentagens da ordem de $50 \%$. Mesmo dividindo aquêle grupo nos grupos etários de 3 a 6 meses e 7 a 11 meses, as porcentagens encontradas foram, respectivamente, $24,6 \%$ e $22,9 \%$, que correspondem a uma queda que não é estatìsticamente significativa. Já no grupo de crianças de 1 a 14 anos de idade a por. centagem de positividade alcança o valor de $51,3 \%$, sendo significativo esta- 
CANDEIAS, J. A. N. - Anticorpos fixadores de complemento para o virus respíratório sincicial e adenovirus. Rev. Saúde públ., S. Paulo, 2(1):44-67, jun. 1968.

tìsticamente o aumento ocorrido entre a classe de 7 a 11 meses e 1 a 6 anos, a primeira com uma porcentagem de positividade de $22,9 \%$, como já referimos, e a segunda, com $53,5 \%$ de soros positivos. Parecem mostrar êstes resultados que, no grupo de crianças examinadas, não só se observou queda inicial dos títulos, como a elevação posterior que se seguiu não foi tão acentuada como a observada por outros autores (CARVALHo, Veronesi \& Fava Neto ${ }^{14}, 1957$; Verovesi, Carvalho \& Fava Netto ${ }^{86}, 1958$; Magureanu, Grobnico \& Musetesco ${ }^{57}$, 1964). Os resultados observados por Pereira, Bruno-Lôbo \& Pereira ${ }^{6}$ (1961) são os que mais se aproximam dos que obtivemos. Não devem, no entanto, ser muito valorizadas estas diferenças ou semelhanças, sabido como é que grande parte delas corre por conta da diversidade das técnicas utilizadas por cada um dos autores.

Os títulos de anticorpos fixadores de complemento não foram muito elevados, distribuindo-se a grande maioria na faixa de 8 e 16. Idênticos resultados foram obtidos por outros autores (CARVALho ${ }^{13}$, 1960; Magureanu, Grobnsco \& Musetesco ${ }^{57}, 1964$ ).

Sempre que se lança mão da reação de fixação de complemento, em inquéritos sorológicos, a primeira consideração a fazer diz respeito a especificidade da mesma: para o vírus respiratório sincicial esta reação é considerada, até o momento, como tipo específico e para os adenovírus ela revela anticorpos grupoespecíficos, com indicação de infecção por qualquer dos tipos sorológicos existentes; já para os vírus parainfluenza as respostas heterotípicas criam um panorama mais complexo em virtude de sua extensão ao vírus da caxumba e ao vírus da doença de Newcastle (Demeio \& W $_{\text {ALKER }}{ }^{27}, 1957$; CoOK et alii ${ }^{24}, 1959$; Hisiung, Isacson \& Tucker ${ }^{43}, 1963$ ). Esta imunidade cruzada é menos evidente nas reações de inibição da hemaglutinação e neutralização (CHANOCK et alii ${ }^{19}, 1960$; HsIUng, Isacson \& TUCKER ${ }^{43}, 1963$ ) e os resultados obtidos devem refletir a experiência da população com êstes vírus. $\mathbf{O}$ aparecimento de anticorpos inibidores da hemaglutinação dá-se nos primeiros anos de vida estando, por altura do oitavo ano de vida, práticamente generalizado para os três tipos de vírus (MogabgaB, Dick \& HolMES ${ }^{59}, 1961$; Chanock et alii ${ }^{20}, 1963$ ). Segundo as observações de LA PlaCA \& Moscovici ${ }^{55}$ (1962) existe uma boa correlação entre os anticorpos neutralizantes e inibidores da hemaglutinação, sendo quase generalizada a observação segundo a qual todos os indivíduos que possuem anticorpos neutralizantes, também possuem anticorpos inibidores $\mathrm{da}$ hemaglutinação. Os resultados obtidos em nossa pesquisa de anticorpos inibido. res de hemaglutinação, no grupo de crianças de idade inferior a 1 ano, correspondem às porcentagens de $39,7 \%$, $42,8 \%$ e $46,1 \%$, respectivamente, para os vírus parainfluenza 1,2 e 3 , só tendo sido considerados positivos os soros de título igual ou superior a 16 . Êstes resultados concordam com os observados por diversos autores (Jensen, Minuse \& ACKermanN ${ }^{47}$, 1955; ChanocK ${ }^{17}, 1956$; Chnock \& Finberg $^{15}$, 1957; KaPikian et alii ${ }^{52}, 1960$; TAYLOR-Robinson \& Brown ${ }^{82}$, 1966; Evans et alii $\left.{ }^{29}, 1967\right)$, exceção feita à porcentagem de soros positivos para o vírus parainfluenza 2. Não se observa queda estatìsticamente significativa quando se comparam os grupos etários de 3 a 6 meses e 7 a 11 meses, mas a partir da idade de 1 ano processa-se uma elevação dos títulos inibidores da hemaglutinação. Analisado em conjunto, o grupo de crianças de idade superior a 1 ano apresenta $47,8 \%$ de soros positivos para o vírus parainfluenza $1,55,7 \%$ para o vírus parainfluenza 2 e $69,7 \%$ para o vírus parainfluenza 3 . Se considerarmos êste grupo subdividido no grupo etário de 1 a 6 anos e 7 a 14 anos, podemos calcular as porcentagens de positividade, que para os vírus parainfluenza 1,2 e 3 são, respectivamente: 
CANDEIAS, J. A. N. - Anticorpos fixadores de complemento para o vírus respiratório sincicial e adenovirus. Rev. Saúde públ., S. Paulo, 2(1):44-67, jun. 1968.

$41,8 \%$ e $55,1 \% ; 48,3 \%$ e $64,6 \%$; $59,8 \%$ e $81,5 \%$. Este panorama sorológico dá-nos uma nítida perspectiva sôbre a porcentagem particularmente elevada de indivíduos com anticorpos inibidores da hemaglutinação para o vírus parainfluenza 2 , achado que não corresponde às considerações feitas por TYRRELL $^{84}$ (1965) em sua revisão sôbre alguns vírus respiratórios, onde salienta a nítida diferença entre a freqüência de infecçôes pelos tipos 1 e 3 e o tipo 2 , sendo êste último o menos constantemente isolado. Porcentagem tão elevada adquire ainda mais importância quando se sabe que o vírus parainfluenza 2 é antigênicamente bastante diferente dos vírus parainfluenza 1 e 3 , sendo pouco frequiente as reações heterotípicas com êstes tipos (Cook et alii ${ }^{24}, 1959$ ).

Quando se analisam as freqüências de distribuição dos títulos de anticorpos inibidores da hemaglutinação no grupo de crianças de idade inferior a 1 ano e se comparam os resultados com os encontrados no grupo de crianças de idade compreendida entre 1 e 14 anos, vê-se que, em ambos os casos, as maiores porcentagens de positividade para os vírus parainfluenza 1 e 2 se distribuem em faixas nas quais os títulos ocupam os valores 16 e 32 . Em relação ao vírus parainfluenza 3 , a porcentagem mais elevada de soros positivos corresponde aos títulos 16 a 128. Também Hsiung, IsacSON \& TUCKER ${ }^{43}$ (1963) observaram semelhante distribuição em crianças e adultos. TAylor-Robinson ${ }^{81}$ (1965) explica esta distribuição para o vírus parainfluenza do tipo 3, como resultante de múltiplas reinfecções.

Distribuição dos anticorpos segundo o sexo - Num grande número de doenças infecciosas, quando se analisa a distribuição de sua incidência segundo o sexo, a participação do sexo masculino é francamente sobrecarregada com maior contingente do quadro clínico em questão, exceção feita à coqueluche (GoRDoN \& Hood $\left.{ }^{38}, 1951\right)$. Seja qual fôr a ex- plicação para esta desproporção e nem sempre há uniformidade de opinião a respeito, sendo invocadas diferenças anatômicas, diferenças no comportamento social, ou simples características do ambiente, a verdade é que em algumas doenças a vírus, particularmente a rubéola (Ivgalls et alli $\left.{ }^{45}, 1960\right)$ e infecções por vírus parainfluenza (FISCHER ${ }^{30}$, 1955) a desigualdade de distribuição é muito evidente.

Nossas observações em relação ao vírus respiratório sincicial e adenovírus não revelam diferenças estatìsticamente significativas para qualquer dos vírus, tanto no grupo de crianças de idade inferior a 1 ano, como no grupo de idade compreendida entre 1 e 14 anos. Mesmo considerando o total de crianças estudadas, independentemente da idade, as porcentagens de positividade para o vírus respiratório sincicial são de $32,3 \%$ nos indivíduos do sexo masculino e $37,4 \%$ nos indivíduos do sexo feminino; para os adenovírus, estas porcentagens tomam os valores de $49,2 \%$ para o sexo masculino e $45,9 \%$ para o sexo feminino, valores que, tal como os primeiros, apresentam diferenças não significativas, estatisticamente.

Já em relação aos vírus parainfluenza pode observar-se que nas crianças de idade inferior a 1 ano, as diferenças ocorridas nas porcentagens de positividade para os vírus parainfluenza 2 e 3 poderiam ser devidas ao acaso, o mesmo não acontecendo para o vírus parainfluenza 1 , com uma porcentagem de positividade de $51,4 \%$ nos indivíduos do sexo masculino e $25,8 \%$ nos indivíduos do sexo feminino. Não encontramos nenhuma razão ponderável capaz de ser utilizada na explicação desta situação. No grupo de crianças de idade superior a 1 ano, as diferenças de positividade observadas, para qualquer dos tipos de vírus parainfluenza, entre os dois sexos, são evidentes e pendem de modo significativo para o sexo masculino, fato que pode estar relacionado com a maior sus- 
CANDEIAS, J. A. N. - Anticorpos fixadores de complemento para o vírus respiratório sincicial e adenovirus. Rev. Saúde públ., S. Paulo, 2(1):44-67, jun. 1968.

ceptibilidade dos indivíduos do sexo masculino aos quadros de laringotraqueobronquite aguda, em cuja etiologia os vírus parainfluenza parecem ter uma marcada participação (FISCHER ${ }^{30}, 1955$ ). Englobando tôdas as idades, no total de 972 crianças observadas, as porcentagens de soros positivos para o vírus parain. fluenza 1 foram de $60,1 \%$, para os indivíduos do sexo masculino e $31,1 \%$, para os do sexo feminino; para o vírus parainfluenza $2,65,1 \%$, para o sexo masculino e $41,2 \%$, para o sexo feminino; para o vírus parainfluenza $3,78,3 \%$ no sexo masculino e $52,9 \%$ no sexo feminino. As diferenças observadas entre os dois sexos são novamente acentuadas e significativas, continuando a ser válida, ou hipotèticamente válida, a explicação anteriormente referida.

Distribuição dos anticorpos, segundo a localização do domicílio - Por si só, a escolha do atributo, localização do domicílio já cria um problema de complexa solução, em virtude da dificuldade de conceituação do que seja, em nosso meio, zona urbana e zona rural. Naturalmente, no início de nosso trabalho não nos coube enfrentar o problema, uma vez que o critério que adotamos foi o seguido pelo SESA, donde recebemos o material para estudo. Mas ao discutirmos os resultados obtidos, em função do atributo escolhido, fomos, fatalmente, enredados na complexidade da questão, complexidade gritante que os numerosos conceitos aí estão testemunhado. Sem querermos entrar no mérito da posição assumida por RAMos ${ }^{69}$ (1961), segundo a qual parece ser lícito aceitar que nos países de estrutura sócio-econômica menos favorecida, os têrmos "rural" e "urbano" perdem muito do seu conteúdo, "quando encarados sob o ponto de vista dos problemas de saúde",é evidente que as excepções encontradas têm de ser levadas em consideração. E a região onde o SESA desempenha suas atividades é uma delas, isto é, abstraindo-se do critério de classificação adotado por aquêle Serviço, não há dúvida que as condições sócioeconômicas ao invés de esvaziarem os têrmos "rural" e "urbano" de seu conteúdo dão, pelo contrário, ao têrmo "urbano" um conteúdo bem mais promissor, em têrmos de saúde pública. Assim não fôsse e talvez não chegássemos aos re. sultados obtidos.

Quando se comparam as porcentagens de positividade para o vírus respiratório sincicial na zona urbana e zona rural, para o conjunto de tôdas as idades, encontram-se respectivamente os valores de $30,5 \%$ e $44,8 \%$, cuja diferença é significativa e para a qual não encontramos outra explicação que não seja a da maior incidência de infecções ocasionadas por êstes vírus, em virtude de precárias condições do ambiente familiar, em têrmos de maior aglomeração de indivíduos, fato de particular importância na epidemiologia de certas viroses (DEL CAMpo \& SANdri ${ }^{26}, 1957$; BRtMblecombe et alii $\left.{ }^{7}, 1958\right)$ e que, eventualmente, pode ser extensivo às infecções pelo vírus respiratório sincicial. As porcentagens de positividade em crianças de idade inferior a 1 ano não são diferentes na zona rural e na zona urbana, o mesmo não sucedendo no grupo de crianças de idade compreendida entre 1 e 14 anos, onde a porcentagem de $47,4 \%$ na zona rural é significativamente diferente da encontrada na zona urbana, com o valor de $32,2 \%$, e dentro do qual se encontra o espectro de idades em que são mais freqüentes as infecções pelo vírus respiratório sincicial. Uma tentativa de explicação do comportamento sorológico do grupo de crianças de idade inferior a 1 ano, poderia levar-nos a aceitar a presença de anticorpos maternos como responsáveis por aquela distribuição das porcentagens de positividade nas zonas urbana e rural.

Esta diferença é particularmente evidente no caso dos adenovírus em que a zona rural participa com uma porcentagem de positividade de $70,1 \%$, enquanto a zona urbana entra com uma porcentagem de $38,7 \%$, quando considerado o 
CANDEIAS, J. A. N. - Anticorpos fixadores de complemento para o virus respiratório sincicial e adenovirus. Rev. Saúde públ., S. Paulo, 2(1):44-67, jun. 1968.

total de crianças, independentemente do grupo etário. A participação dos adenovírus em quadros diarréicos (GARDNER, MeGregor \& DicK ${ }^{33}, 1960 ;$ GardNer et alii ${ }^{34}, 1962$; Potrer ${ }^{67}, 1964$ ), pode explicar esta elevada porcentagem de positividade para a zona rural, onde condiçôes sanitárias conhecidamente precárias muito contribuem para a explosão de surtos diarréicos. As porcentagens de positividade para os adenovírus nas zonas urbana e rural não se mostram diferentes no grupo de idade inferior a 1 ano; no grupo de mais de 1 ano de idade, aquelas diferenças são, novamente, a favor da zona dural. Também, neste caso os anticorpos maternos estariam justificando o diferente comportamento das crianças de idade inferior a 1 ano.

Finalmente, as porcentagens de positividade para os vírus parainfluenza 1,2 e 3 não apresentam diferenças significativas nas zonas urbana e rural, quando se estuda a sua distribuição nas crianças de idade inferior a 1 ano $e$ nas crianças de 1 ano e mais. Englobando, no entanto, tôdas as idades as porcentagens de positividade calculadas tomam os seguintes valores: vírus parainfluenza $\mathbf{I}$, $47,9 \%$ para a zona urbana e $43,8 \%$ para a zona rural; virus parainfluenza 2 , $57,1 \%$ para a zona urbana e $46,8 \%$ para a zona rural; vírus parainfluenza 3 , $67,1 \%$ para a zona urbana e $65,4 \%$ para a zona rural. Só a diferença entre as porcentagens de positividade para o vírus parainfluenza 2 são significativas, fato para o qual não encontramos explicação, a menos que se considere que uma de suas características epidemiológicas, baixa endemicidade (CHANOCK et alii $\left.{ }^{20}, 1963\right)$, crie condiçôes particulares para um comportamento diverso daquele apresentado pelos tipos 1 e 3 .

\section{CONCLUSOES}

Terminamos o presente trabalho com alguns fatos que nos parecem bem estabelecidos e que passam a ser enunciados, como conclusões, do modo seguinte:
1. No grupo de 972 crianças estudadas, demonstramos a existência de anticorpos fixadores de complemento para o vírus respiratório sincicial e adenovírus e de anticorpos inibidores de hemaglutinação para os vírus parainfluenza dos tipos 1,2 e 3 .

2. Os anticorpos fixadores de complemento para o vírus respiratório sincicial foram encontrados em $20,7 \%$ das crianças de idade inferior a 1 ano e $36,7 \%$ das crianças de idade compreendida entre 1 e 14, anos, distribuição sensìvelmente inferior à referida noutras publicações. Com base nestes resultados amostrais, depositamos $95 \%$ de confiança na afirmação de que:

a) das crianças de idade inferior a 1 ano, inscritas no SESA, a proporção das que possuem anticorpos fixadores de complemento para o vírus respiratório sincicial está compreendida entre $14,3 \%$ e $29,6 \%$;

b) das crianças de 1 ano e idades superiores, inscritas no SESA, a proporção das que possuem anticorpos fixadores de complemento para o vírus respiratório sincicial está compreendida entre $33,8 \%$ e $39,6 \%$.

3. A distribuição dos anticorpos fixadores de complemento para o vírus respiratório sincicial, segundo o sexo, não apresenta diferença significativa.

4. A distribuição dos anticorpos fixadores de complemento para o vírus respiratório sincicial, segundo a localização do domicílio, apresenta diferença significativa; encontra-se porcentagem de positividade mais elevada na zona rural.

5. Os anticorpos fixadores de complemento para adenovírus foram encontrados em $23,8 \%$ das crianças de idade inferior a 1 ano e $51,3 \%$ das crianças de idade compreendida entre 1 e 14 anos, distribuição sensivelmente inferior à re- 
CANDEIAS, J. A. N. - Anticorpos fixadores de complemento para o virus respiratório sincicial e adenovirus. Rev. Saúde públ., S. Paulo, 2(1):44-67, jun. 1968.

ferida noutras publicaçóes. Com base nestes resultados amostrais, depositamos 95\% de confiança na afirmação de que:

a) das crianças de idade inferior a 1 ano, inscritas no SESA, a proporção das que possuem anticorpos fixadores de complemento para adenovírus está compreendida entre $16,4 \%$ e $30,7 \%$;

b) das crianças de 1 ano e idades superiores, inscritas no SESA, a proporção das que possuem anticorpos fixadores de complemento para adenovírus está compreendida entre $48,2 \%$ e $54,4 \%$.

6. A distribuição dos anticorpos fixadores de complemento para adenovírus, segundo o sexo, não apresenta diferença significativa.

7. A distribuição dos anticorpos fixadores de complemento para adenovírus, segundo a localização do domicílio, apresenta diferença significativa; encontra-se porcentagem de positividade mais elevada na zona rural.

8. Os anticorpos inibidores da hemaglutinação para os vírus parainfluenza dos tipos 1,2 e 3 foram encontrados, respectivamente, em $39,7 \%, 42,8 \%$ e $46,0 \%$ das crianças de idade inferior a 1 ano e em $47,8 \%, 55,7 \%$ e $69,7 \%$ das crianças de idade compreendida entre 1 e 14 anos, distribuição semelhante à referida noutras publicaçōes, exceção feita à relativa ao vírus parainfluenza do tipo 2 que, em nosso caso, é sensìvelmente superior. Com base nestes resultados amostrais, depositamos 95\% de confiança na afirmação de que:

a) das crianças de idade inferior a I ano, inscritas no SESA, a proporção das que possuem anticorpos inibidores da hemaglutinação para os vírus parainfluenza dos tipos 1, 2 e 3 está, respectivamen. te, compreendida entre $31,5 \%$ e $47,9 \% ; 34,5 \%$ e $51,1 \% ; 37,6 \%$ e $54,4 \%$;

b) das crianças de 1 ano e idades superiores, inscritas no SESA, a proporção das que possuem anticorpos inibidores da hemaglutinação para os vírus parainfluenza dos tipos 1, 2 e 3 está, respectivamente, compreendida entre $46,2 \%$ e $49,4 \% ; 54,1 \%$ e $57,3 \% ; 68,1 \%$ e $71,2 \%$.

9. A distribuição dos anticorpos inibidores da hemaglutinação para os vírus parainfluenza dos tipos 1,2 e 3 , segundo o sexo, apresenta diferenças significativas; encontram-se porcentagens de positividade mais elevadas no sexo masculino.

10. Entre os vírus parainfluenza, sòmente a distribuição dos anticorpos inibidores da hemaglutinação para o vírus parainfluenza do tipo 2 , segundo a locan lização do domicílio, apresenta diferença significativa; encontra-se porcentagem de positividade mais elevada na zona urbana.

\section{S U M M A R Y}

The author presents the results of a survey for respiratory syncytial virus and adenovirus complement fixing antibodies and parainfluenza viruses $1,2,3$ haemagglutination inhibition antibodies in a group of 972 chidren between 3 months and 14 years of age. The filter paper method of collecting whole blood was used. Altogether, the percentage of children with complement fixing antibodies against respiratory syncytial virus and adenovirus were respectively $34.6 \%$ and $47.7 \% ; 46.8 \%, 54.1 \%$ and $66.6 \%$ possessed haemagglutination inhibition antibodies against parainfluenza virus types 1,2 and 3 . A study on the distribution of the antibodies according to different age groups was also conducted. The 
CANDEIAS, J. A. N. - Anticorpos fixadores de complemento para o virus respiratório sincicial e adenovírus. Rev. Saúde públ., S. Paulo, 2(1):44-67, jun. 1968.

present study was undertaken, in order, to examine the distribution of antibodies according to sex and home localization. The following results were obtained: $32.3 \%$ of the boys possessed antibodies against respiratory syncytial virus, $49.2 \%$ against adenovirus and $60.1 \%, 65.5 \%$ and $78.3 \%$ against parainfluenza viruses $1,2,3$ respectively; percentages in girls were $37.4 \%, 45.9 \%, 31.1 \%, 41.2 \%$ and $52.9 \%$ respectively. In the rural area $44.8 \%$ of the children possessed antibodies against respiratory syncytial virus, $70.1 \%$ against adenovirus, $43.8 \%$ against parainfluenza virus type 1 and $46.8 \%$ and $65.4 \%$ against parainfluenza viruses 2,3 ; in the urban area the percentages observed were, respectively, $30.5 \%, 38.7 \%, 47.9 \%, \quad 57.1 \%$ and $67.1 \%$.

\section{A GRADECIMENTOS}

Manifestamos nosso reconhecimento à Srta. Eunice Pinho de Castro Silva e ao Sr. José Maria Pacheco de Souza, instrutores do Departamento de Estatística Aplicada, da Faculdade de Higiene e Saúde Pública, pela orientação nas provas estatísticas que realizamos. Ao Dr. Amaury de Castro Monteiro, Diretor do Serviço Especial de Saúde de Araraqua$\mathrm{ra}$, os nossos agradecimentos pelo valioso auxílio que nos prestou na obtenção do material utilizado na presente pesquisa.

\section{REFERENCIAS BIBLIOGRAFFICAS}

1. AMERICAN PUBLIC HEALTH ASSOCIATION (APHA) - Diagnostic procedure for viral and rickettsial diseases. 3rd ed. New York, 1964.

2. ANDREWES, C. H. et alii - Propagation of common cold virus in tissue cultures. Lancet, 2(6785):346-547, Sept. 1953.

3. BEEM, M. - Repeated infections with respiratory syncytial virus. J. Immunol., 98(6): 1115-1122, July, 1967.
4. BEEM, M. et alii - Asociation of the chimpanzes coryza agent with acute respiratory disease in children. New Engl. J. Med., 263(11):525-530, Sept. 1960.

5. BERGLUND, B.; VIHMA, L. \& WICKSTROM, J. - Respiratory syncytial virus studies on children hospitalized during an outbreak of respiratory illness in Finland. Amer. J. Epidemiol., 81 (3):271-281, May, 1965.

6. BRADSTREET, C. M. P. \& TAYLOR, C. E. D. - Technique of complement fixation test applicable to the diagnosis of virus diseases. Monthly Bull. Minist. Hlth, 21:96-104, Jan. 1962.

7. BRIMBLECOMBE, F. S. W. et alii Family studies of respiratory infections. Brit. med. J., 1(5063):119-128, Jan. 1958.

8. BRODY, J. A. et alii - Use of dried whole blood collected on filter paper discs in adenoviruses complement fixation and measles haemagglutinationinhibition tests. $J$. Immunol., 92(6): 854-857, June, 1964.

9. BRUNO-LÓBO, G.; PEREIRA, M. S. \& PEREIRA, H. G. - Estudos sôbre adenoviroses no Rio de Janeiro. $A n$. Microbiol. Rio de J., 9(pt C):567-578, 1961.

10. BUFFE, D. \& BURTIN, P. - Formation des immunoglobulines chez le foetus et le jeune enfant. Ann. Inst. Pasteur, 112(4):468-475, Avr. 1967.

11. CANDEIAS, J. A. N. \& CHRISTOVAO, D. de A. - Pesquisas de anticorpos fixadores de complemento para vírus respiratório sincicial em grupos de população do Território Federal do Amapá, Brasil. Arq. Fac. Hig. S. Paulo, 20(1): 87-97, jun. 1966.

12. CANDEIAS, J. A. N. \& HIMELFARB, L. - Pesquisa de anticorpos fixadores de complemento para vírus respiratório sincicial em habitantes da cidade de São Paulo. Arq. Fac, Hig. S. Paulo, 20(2) :207-213, dez. 1966.

12a. CANDEIAS, J. A. N. - Isolamento de vírus respiratório sincicial em crianças com quadros respiratórios agudos. Rev. Inst. Med. trop. S. Paulo, 9(1):27-30, jan. 1967.

13. CaRvalHo, R. P. S. - Contribuição para o estudo dos adenovirus. São Pau1o, 1960. (Tese de Doutoramento Fac. Med. Univ, S. Paulo). 
CANDEIAS, J. A. N. - Anticorpos fixadores de complemento para o virus respiratório sincicial e adenovírus. Rev. Saúde públ., S. Paulo, z(1):44-67, jun. 1968.

14. Carvalho, R. P. S.; VERONESI, R. \& FAVA NETTO, $\mathrm{C}$ - Adenovíroses. Verificacão de sua existência em São Paulo, através de inquérito sorológico (R.F.C.). Rev. Med. Cirurg. S. Paulo, $17(11 / 12): 475-476$, nov./dez. 1957.

15. CHANOCK, R. \& FINBERG, L. - Recovery from infants with respiratory illness of a virus related to chimpanzee coryza agent (C.C.A.). II. Epidemiologic aspects of infection in infants and young children. Amer. J. Hyg., 66 (3) :291-300, Nov. 1957

16. CHANOCK, R.; ROIZMAN, B. \& MYERS, R. - Recovery from infants with respiratory lllness of a virus related to chimpanzee coryza agent (C.C.A.). II. Isolation, properties and characterization. Amer. J. Hyg., 66(3):281-290, Nov. 1957.

17. CHANOCK, R. M. - Association of a new type of cytopathogenic myxovirus with infantile croup. J. exp. Med., 104 (4) :555-576, Oct. 1956.

18. CHANOCK, R. M. et alii - Newly re cognized myxoviruses from children with respiratory disease. New Engl. J. Med., 258(5) :207-213, Jan. 1958.

19. CHANOCK, R. M. et alii - Serological response of individuals infected with parainfluenza viruses. Amer. J. publ. Hlth, 50(12):1858-1859, Dec. 1960.

20. CHANOCK, R. M. et alii - Myxoviruses parainfluenza. Amer. Rev. resp. Dis., $88(3): 152-166$, Sept. 1963.

21. CHIN, J. et alii - Filter paper disc method of collecting whole blood for serologic studies in children. Amer. $J$. Epidemiot., 84(1):74-80, July, 1966.

22. COATES, H. V. et alii - An antigenic analysis of respiratory syncytial virus isolates by a plaque reduction neutralization test. Amer. J. Epidemiol,, $\mathbf{8 3}$ (2) :299-313, Mar. 1966

23. COMMITTEE ON ECHO VIRUSES Enteric cytopathogenic human orphan (ЕCHO) viruses. Science, 122(3181): 1187-1188, Dec. 1956.

24. COOK, M. $K$. et alil - Antigenic relationship among the "newer" myxoviruses (parinfluenza). Amer. J. Hyg., 69 (3) :250-264, May, 1959.
25. DALLDORF, G. \& SICKLES, G. M. An unidentified, filtrable agent isolated from the feces of children with paralysis. Science, 108(2792):61-62, July, 1948.

26. DEL CAMPO, A. \& SANDRI, G. - Osservazioni cheniche ed epidemiologiche su di una recente epidemia di malattia acute respiratoria (A.R.D. nell'infanzia). Minerva med., 48(98):4178-4184, dec. 1957.

27. DEMEIO, J. L. \& WALKER, D. L. Demonstration of antigenic relationship between mumps virus and haemagglutinating virus of Japan. J. Immunol, 78(6) : 465-471, June, 1957.

28. DOGGETT, J. E. - Antibodies to respiratory syncytial virus in human sera from different regions of the world. Bull. Wld. Hlth. Org., 32(6):849-853, June, 1965.

29. EVANS, A. S. et alii - Acute respiratory disease in University of the Philippines and University of Wisconsin students. A comparative study. Bull. Wld. Hith Org., 36(3):397-407, 1967.

30. FISCHER, H. J. W. - Acute laryngo-tracheo-bronchitis. Practitioner, 175 (1050) : 700-706, Dec. 1955.

31. FUDENBERG, H. H. \& FUNDENBERG, B. R. - Antibody to hereditary human gamme-globulin (Gm) factor resulting from maternal fetal incompatibility. Science, 145(3628):170-171, July, 1964.

32. GARDNER, P. S.; ELDERKIN, F. 'M. \& WALL, H. A. - Serologic study of respiratory syncytial virus infections in infancy and childhood. Brit. med. J., 2 (5424) :1570-1573, Dec. 1964.

33. GARDNER, P. S.; Mc GREGOR, C. B. \& DICK, K. - Association between diarrhoea and adenovirus type 7. Brit. med. J., $1(5166): 91-93$, Jan. 1960.

34. GARDNER, P. $S$. et alii - Virus infection and intussusception in childhood. Brit. med. J., $2(5306): 697-700$, Sept. 1962.

35. GINSBERG, H. S. et alii - Relation of the new respiratory agents to acute respiratory diseases. Amer. J. publ. Hlth, 45(7):915-922, July, 1965. 
CANDEIAS, J. A. N. - Anticorpos fixadores de complemento para o vírus respiratório sincicial e adenovirus. Rev. Saúde públ., S. Paulo, 2(1):44-67, jun. 1968.

36. GNESH, G. M. - Serologic surveys for respiratory virus antibodies in New York State. Hlth. Lab. Sci., $2(2): 89-92$, Apr. 1965.

37. GOLD, R. Z. - On comparing multinomial probilities. Brooks (Tex.), School of Aerospace Medicine, 1962.

38. GORDON, J. E. \& HOOD, R. I. Whooping cough and its epidemiological anomalies. Amer. J. med. Sci., 222 (3) :333-361, Sept. 1951

39. GWALTNEY, J. M. - Micro-neutralization test for identification of rhinovirus serotypes. Proc. Soc. exp. Biol, New York, 122(4):1137-1141, Aug./Sept. 1966.

40. HAMBLinG, M. M. - A survey of antibodies to respiratory syncytial virus in the population. Brit. med. J, 1 (5392) :1223-1225, May, 1964.

41. HillemaN, M. R. et alli - Epidemiologic investigation with respiratory disease virus RI-67. Amer. J. Publ. Hlth, 45(1):203-210, Jan. 1955.

42. HORNSLETH, A. \& VOLKERT, M. The incidence of complement fixin antibodies to the respiratory syncytial virus in sera from Danish population groups aged 0,10 years. Acta path. microbiol. scand., 62(3):421-431, Feb. 1964.

43. HSIUNG, G. D.; ISACSON, P. \& TUCKER, G. - Studies of parainfluenza viruses. II. Serologic interrelationship in humans. Yale J. Biol. Med., 35(6): 534-544, June, 1963.

44. HUEBNER, R. J. - Viral respiratory disease in Americas. Amer. Rev. resp. Dis., 88(3):1-13, Sept. 1963.

45. INGALLS, T. H. et alil - Rubella: its epidemiology and teratology. Amer. $J$. Med. Sci., 239(3):363-383, Mar. 1960.

46. JAMIESON, S. P.; ALEXANDER, J. G. \& TEAL, F. - Respiratory syncytial virus epidemic. Publ. Hlth, London, 80 (4) :194-200, May, 1966.

47. JENSEN, K. E.; MINUSE, E. \& ACKERMANN, W. W. - Serologic evidence of american experience with newborn pneumonitis virus (type Sendai), J. Immunol., 75 (1) :71-77, July, 1955.

48. JOHNSON, K. M. et alii - Studies of a new human hemadsorption virus. T. Isolation, properties and characteri- zation. Amer. J. Hyg., $71(1): 81-92$, Jan. 1960.

49. JORDAN Jr., W. S.; BADGER, G. F. \& DINGLE, J. H. - A study of illness a group of Cleveland families. XV. Acquisition of type especific adenovirus antibodies in the first five year of life. New Engt. J. Med., 258(21):1041-1044, May, 1958 .

50. JORDAN Jr., W. S. et alii - A study of illness in a group of Cleveland families. $X$. The occurrence of adenovirus infections. Amer. J. Hyg., 64(3): 336-348, Nov. 1956.

51. KALTER, S. S. - Disc method for identification and titration of citopathic viruses and detection of antibodies resulting from their infection. $J$. Lab. Clin. Med., 62(3):525-534, sept. 1963.

52. KAPIKIAN, A. Z. et alii - A study of the hemadsorption viruses (parainfluenza) and other viruses in children with and without respiratory disease. Pediatrics, 26(2):243-254, Aug. 1960.

53. KATZ, S. et alii - Studies of complement-fixing and neutralizing antibodies against certain adenovirus. $J$. Immunol., 78(2):118-121, Feb. 1957.

54. KUROYA, M. et alii apud ANDREWS, C. H. - The common cold and other minor respiratory infections. Brit. med. Bull., 15(3) :221-224, sept. 1959.

55. LA PLACA, M. \& MOSCoviCI, C. Distribution of parainfluenza antibodies in different groups of population. $J$. Immunol,, 88(1):72-77, Jan. 1962.

56. LEADING ARTICLES - A defense against viruses. Lancet, 1(7489):549551, Mar. 1967.

57. MAGUREANU, E.; GROBNICO, M. \& MUSETESCO, M. - Anticorps adenoviraus. Etude sérologique de leur incidence dans divers groups de population. Presse méd., ๆ2(52):3113-3115, déc. 1964.

58. McCLELLAND, L. et alii - Studies of acute respiratory illnesses caused by respiratory syncytial virus. II. Epidemiology and assessment of importance. New Engl. J. Med., 264(23):1169-1175, June, 1961.

59. MOGABGAB, M. J.; DICK, E. C. \& HOLMES, B. - Parainfluenza 2 (CA) 
CANDEIAS, J. A. N. - Anticorpos fixadores de complemento para o vírus respiratório sincicial e adenovírus. Rev. Saúde públ., S. Paulo, 2(1):44-67, jun. 1968.

virus in young adults. Amer. J. Hyg., 74 (3) : 304-310, Nov. 1961.

60. MORRIS, J. A.; BLOUNT, R. E. \& SAVAGE, R. E. - Recovery of cytopathogenic agent from chimpanzees with coriza. Proc. Soc. exp. Biol. New York, $92(3)$ :544-549, July, 1956.

61. MOSS, P. D.; ADAMS, M. O. \& TOBIN, J. O. H. - Serological studies with respiratory syncytial virus. Lancet, 1 (7276) : 298-300, Feb. 1963.

62. PARROTT, R. H. et alii - Serologic studies over a 34-month perlod of children with bronchiolitis, pneumonia and minor respiratory diseases. J.A.M.A., 176 (7):653-657, May, 1961.

63. PEREIRA, M. S.; BRUNO-LOBO, G. S. \& PEREIRA, H. G. - Inquérito sorológico sôbre a incidéncia de certas vìroses respiratórias do Rlo de Janeiro. An. Microbiol., Rio de Janeiro, 9(pt. C): 579-589, 1961.

64. PEREIRA, M. S. \& MacCALLUM, F. O. - Infection with adenovirus type 12. Lancet, 1(7326):198-199, Jarf. 1964.

65. PIKE, R. M. - Antibody heterogeneity and serological reactions. Bact. Rev., 31(1):157-174, June, 1967.

66. PORTNOY, B. et alii - The sensitivity of the complement fixation test for the detection of adenovirus infections in infants and children with lower respiratory disease. Amer. J. Epidemiol., 86(2):362-371, Sept. 1967.

67. POTTER, C. W. - Adenovirus infections as an etiological factor in interssusception of infants and young children. J. Path. Bact., 88(1):263-274, July, 1964.

68. POTTER, C. W. \& SHEDDEN, W. I. H. - The distribution of adenovirus antibodies in normal children. J. Hyg., Cambridge, 61(1):155-160, Mar. 1963.

69. RAMOS, R. - Consideração sôbre o problema da assistência médico-sanitária em áreas rurals. Arq. Hig. São Paulo, 88(26):109-119, jun. 1961.

70. RICHARDSON, F. M. - Preservation of liquid complement serum. Lancet, 2 (6171):696-697, 1941.
71. ROWE, W. P. et alii - Isolation of a citopathogenic agent from human adenoid undergoing spontaneous degeneration in tissue culture. Proc. Soc. exp. Biol., New York, 84(3):570-573, Dec. 1953.

72. ROWE, W. P. et alii - Studies of the adenoldal-pharyngeal-conjunctival (APC) group of viruses. Amer. J. Hyg., 61(3): 197-218, Mar. 1955.

73. SALIBA, G S.; GLEZEN, W. P. \& CHIN, T. D. Y. - Etiologic studies of acute respiratory iliness among children attending public schools Amer. Rev. resp. Dis., 95(4) :592-602, Apr. 1967.

74. SCHMIDT, N. J.; LENNETTE, E. H. \& KING, C. J. - Neutralizind haemagglutination-inhibiting and group complement-fixing antibody response in human adenovirus infections J. Immunol., 97(1):64-74, July, 1966.

75. SEVER, J. L. - Application of a microtechnique to viral serological investigations. J. Immunol., 88(3):320-329, Mar. 1962.

76. SILVERSTEIN, A. M. et alil - Fetal response to antigenic stimulus. II. Antibody production by the fetal lamb. J. exp. Med., 11y(5):799-812, May, 1963.

77. SMITH, C. B. et alii - Protective effect of antibody to parainfluenza type 1 virus. New Engl. J. Med., 275(21): 1145-1151, Nov. 1966.

78. SOUZA, S L. CAMARGO, M. E. The use of filter paper blood smears in a practical fluorescent test for american trypanosomiais serodiagnosis. Rev. Inst. Med. trop. S. Paulo, 8(6):255-258, nov./dez. 1966

79. STANLEY, N F.; DORMAN, C. D. \& PONSFORD, J. - Studies on the hepatoencephalonyelitis virus (HEV). Aust. J. exp. Biol. Med. Sci., 32(4):543-562, Aug 1954.

80. TAKATSY, G. apud SEVER, J. L. et alit - Serological diagnosis "en masse" with multiple antigens. Amer. $J$. resp. Dis., 88(3) :342-359, Sept. 1963.

81. TAYLOR-ROBINSON, D. - Respiratory virus antibodies in human sera from different regions of the world. Bull. Wld. Flth. Org., 32(6):833-847, June, 1965. 
CANDEIAS, J. A. N. - Anticorpos fixadores de complemento para o virus respiratório sincicial e adenovirus. Rev. Saride pribl., S. Paulo, 2(1):44-67, jun. 1968.

82. TAYLOR-ROBINSON, D. \& BROWN, P. - Respiratory virus antibodies of persons living in isolated communities. Bull. Wld. Hlth. Org., 34(6):895-900, 1966.

83. TOSI, H. C. et alii - Encuesta seroepidemiologica sobre infecciones por adenovirus, realizadas por el método de gel difusión. Ann. Fac. Med. Montevideo, $49(3 / 4)$ : 428-431, 1964.

84. TYRRELL, D. A. J. - A collaborative study of the etiology of acute respiratory infections in Britain - 1961-64. Brit. med. J., 2(5457):319-326, Aug. 1965.

85. VAN DER VEEN, J. - The role fo adenoviruses in respiratory disease. Amer. Rev resp. Dis., 88(3):167-180, Sept. 1963.
86. VERONESI, R.; CARVALHO, R. P. S. \& FAVA NETTO, C. - Viroses do aparêlho respiratório. Comprovação da infeccão pelos "vírus hemadsorventes" e adenovirus em diferentes grupos etários de São Paulo. Rev. Hosp. Clin. Fac. Med. S. Paulo, 13(5):355-362, set. 1958.

87. WEIBEL, R. E. et alii - Respiratory virus vaccines. $V$. Field evaluation for efficacy of heptavalent vaccine. Amer. Rev. resp. Dis., 94(3):362-379, Sept. 1966.

88. WENNER, H. A. et alii - The epidemiology of acute respiratory illness. I. Observation on adenovirus infections prevailing in a group of families. $J$. Infec. Dis., 101(3):275-283, Nov. 1957.

89. WORTH, R. M. - The filter disc blood collection method adapted for a mumps HAI serologic survey. Amer. J. Hyg., 79 (3) :245-249, May, 1964. 